\title{
Morphometric and colourimetric tools to dissect morphological diversity: an application in sweet potato [Ipomoea batatas (L.) Lam.]
}

\author{
Amparo Rosero $\mathbb{D} \cdot$ Leiter Granda $\cdot$ José-Luis Pérez $\cdot$ Deisy Rosero \\ William Burgos-Paz $\cdot$ Remberto Martínez $\cdot$ Julio Morelo $\cdot$ Iván Pastrana • \\ Esteban Burbano $\cdot$ Alfredo Morales
}

Received: 16 January 2019/Accepted: 22 April 2019/Published online: 5 June 2019

(C) The Author(s) 2019

\begin{abstract}
The genetic diversity of sweet potato [Ipomoea batatas (L.) Lam.] and its wild relatives has been collected and conserved in germplasm collections worldwide and explored employing several tools. The characterization of crops diversity through morphological tools produce useful information. However, the use of conventional morphological descriptions exhibits limitations due to the use of subjective and categorical parameters that affect phenotypic description and diversity estimation. In
\end{abstract}

A. Rosero $(\bowtie) \cdot$ J.-L. Pérez · W. Burgos-Paz ·

R. Martínez · J. Morelo · I. Pastrana - E. Burbano

Corporación Colombiana de Investigación Agropecuaria

(AGROSAVIA), Turipana, Km 13 via Monteria, Cereté,

Colombia

e-mail: erosero@agrosavia.co

J.-L. Pérez

e-mail: jlperez@agrosavia.co

W. Burgos-Paz

e-mail: wburgos@agrosavia.co

R. Martínez

e-mail: rmartinez@agrosavia.co

J. Morelo

e-mail: jmorelo@agrosavia.co

I. Pastrana

e-mail: ipastrana@agrosavia.co

E. Burbano

e-mail: eburbano@agrosavia.co order to increase the efficiency to discriminate different phenotypes not detected by conventional morphological descriptors, new phenomic approaches were used. Seventy sweet potato accessions collected in the northern coast of Colombia were characterized by forty-nine parameters from conventional sweet potato descriptors and data obtained by RGB imaging and colourimetry. Field descriptions, RGB imagingcolourimetry and both databases integrated were analysed using Gower's general similarity coefficient

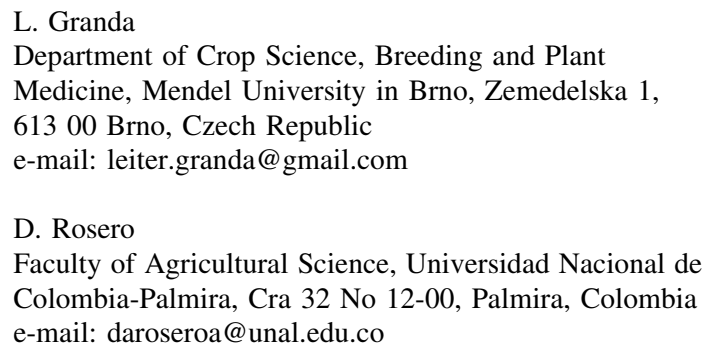

L. Granda

Department of Crop Science, Breeding and Plant Medicine, Mendel University in Brno, Zemedelska 1, 61300 Brno, Czech Republic

e-mail: leiter.granda@gmail.com

D. Rosero

Faculty of Agricultural Science, Universidad Nacional de Colombia-Palmira, Cra 32 No 12-00, Palmira, Colombia e-mail: daroseroa@unal.edu.co
A. Morales
Instituto de Investigaciones de Viandas Tropicales (INIVIT), Apartado 6, CP 53000 Santo Domingo, Villa Clara, Cuba
A. Rosero
Centro de conservación de cultivos andinos nativos CANA - ORII Tierra y Vida. Km 5 vía Carlosama-Panan, Cumbal, Colombia 
for clustering. Estimation of genotype similarity was significantly improved when quantitative data obtained by RGB imaging and colourimetry analysis were included. Variations in traits such as flesh and periderm colour in roots, leaves, vein colour and leaf shape that were not detected by field descriptors, were efficiently discriminated by measuring pixel values from images, estimation of shape descriptors (circularity, solidity, area) and colourimetry data. Expected high correlations were found for field parameters (number of lobes, lobe type, and central lobe shape) and image data (circularity, roundness and solidity). The combination of RGB imaging and colourimetry benefits the quality of morphological characterizations, resulting in a cost-effective process that is able to identify polymorphisms and target traits for diversity estimation and breeding.

Keywords Sweet potato $\cdot$ Morphological characterization · Morphometry $\cdot$ Colourimetry $\cdot$ RGB imaging

\section{Introduction}

Sweet potato [Ipomoea batatas (L.) Lam.] is an important tropical American crop belonging to the Convolvulaceae family; it is a hexaploid species $(2 n=6 x=90)$ with high levels of heterozygosity (Austin and Huamán 1996), and therefore, it has a wide variation in botanical characteristics and is readily distinguished based of morphological traits, yield potential, size, shape, flesh and skin colour of roots, as well as size, colour and shape of leaves and branches (Acheampong 2012; Zhang et al. 2000). Sweet potato is the fifteenth most important food crop, and the third among roots and tubers crops, being cultivated on ca. 8.6 million hectares worldwide, producing about 106 million tons, with an average yield of about $12.2 \mathrm{t} / \mathrm{ha}$. China is the major producer of sweet potato in the world, followed in order by Nigeria, Tanzania, Indonesia, Uganda, Ethiopia, Angola, India, the United States of America, Vietnam and Madagascar (FAOSTAT 2016).

Sweet potato has the capacity to adapt to different environmental conditions, being an important feature to ensure human food security in vulnerable regions (Glato et al. 2017). Hence, sweet potato is an alternative crop with the ability to grow and produce under adverse conditions, and therefore, it is an important plant genetic resource valuable for research, plant breeding, conservation, and to encourage consumption (Rahaman et al. 2015).

Diversity studies in sweet potato around the world have allowed recognizing the genetic variability present in this crop species. In Peru, sweet potato remains dated from 8000 years ago have been found (Lebot 2010); however, according to the morphological variability, the greatest diversity in the Americas was found in Colombia, Peru and Ecuador (Yen 1982). Due to the high diversity found in the Americas, this area has been suggested as a possible centre of origin (Austin 1988; Zhang et al. 2000; Templar et al. 2003; Rodríguez et al. 2017, Mwanga et al. 2017). Nevertheless, the Americas have been the main source of germplasm from where genetic materials were obtained and introduced to other continents; even in the case of Africa that is a centre of diversity for this species, Zhang et al. (2004) reported that its introduction route was from South America to the east African borders. According to sweet potato studies carried out in Polynesia, taking into account the lexical similarity between the Polynesian languages and the Quechua language of South America, it was inferred that there was a possibility that this crop could have been introduced from South America (Scaglion 2005; Clarke 2009). New Guinea is another centre of diversity for sweet potato; however, New Guinea landraces are mainly derived from the northern Neotropical gene pool (i.e. from the Caribbean and Central America) and later reintroductions from South American clones were probably recombined with existing genotypes. Diversity among New Guinea landraces suggests that sexual reproduction, rather than somaclonal variation, has played a predominant role in the diversification of sweet potato (Roullier et al. 2013). Other centres of diversity are the west Pacific comprising China, Japan and Korea (Zhang et al. 2004; Montenegro et al. 2008).

Morphological characterizations have been used as a first step in plant diversity assessments for both the conservation and use of plant genetic resources (Mwanga et al. 2017). In sweet potato several studies used this approach to quantify diversity in a specific geographical area, to eliminate duplicated accessions in germplasm banks and produce important information for sweet potato breeding (Veasey et al. 2007; 
Koussao et al. 2014). Characterization of plant morphology requires to measure vegetative and reproductive structures (Huamán 1999). Previous studies showed high variability in sweet potato landraces employing vegetative and reproductive morphology based in conventional sweet potato descriptors (Veasey et al. 2007). Similarly, morphological characterizations have also been used to evaluate ecotypes in water deficit conditions and their productive potential, which allowed identifying promising ecotypes that were introduced in improvement programs (Maquia et al. 2013). However, previous studies in several crops showed the limitations of solely using a standard morphological characterization, specially to describe fruit shape in scarlet and gboma eggplants complexes (Plazas et al. 2014; Kaushik et al. 2016), in tomato (Figàs et al. 2015) and in papaya (Marmolejo et al. 2017). Thus, morphological characterization sometimes becomes a time-consuming process that increases the chance of generating errors in trait measurements (Kumar et al. 2015).

Currently, several approaches for plant phenotyping have been developed to evaluate the diversity based in image analysis (Gehan et al. 2017); these strategies allow performing a morphological characterization using an image as a non-destructive tool for plant analysis. In Arabidopsis and other species such as tomatoes and grapes, this approach has been used to obtain biometric measurements of shapes and of the complexity of plant organs, as well as pigments in tissues, among others (Chitwood et al. 2013). In barley, morphological descriptors showed poor level of diversity congruence observed in important genetic characters (Cross et al. 1992); furthermore, morphometric approaches for leaf shape characterization showed to be an accurate phenotypic analysis that has been used to describe quantitatively diverse patterns of blade outgrowth, hirsuteness and venation patterning (Chitwood et al. 2013; 2014; Lockhart 2013). Similarly, other visual characters such as the colour of mature and immature leaves, abaxial vein, root flesh, etc., are subjectively evaluated and mainly based in few categorical options. The establishment of the mean red, green and blue pixel values from RGB images, improved organ colour discrimination that was not detected by visual evaluation (Kendal et al. 2013). Similarly, $\mathrm{L}^{*}, \mathrm{a}^{*}$, and $\mathrm{b}^{*}$ components have been successfully used for evaluations and plant recognition (Schmittmann and Schulze Lammers
2017) in the characterization of fruits or food quality (Itle and Kabelka 2009; Lopez and Gomez 2004).

According to the aforementioned facts, the aim of this study was to evaluate a low-cost method using RGB images to estimate colour pixel values, morphometric parameters and coverage area in the field, as well as colourimetry, as a strategy to improve conventional morphological characterization of sweet potato accessions.

\section{Materials and methods}

Plants

Seventy sweet potato samples traditionally cultivated in the northern coast of Colombia were collected according to the permission obtained by Agrosavia from the national environmental licensing authority of Colombia for the collection of specimens from the national biological diversity for scientific non-commercial research. Any sample of the Ipomoea genus is currently found in the list of species protected by CITES; sample identification was carried out by I. Pastrana and A. Rosero (AGROSAVIA). Several morphological polymorphisms were visually detected among the collected samples.

\section{Growth conditions}

Cuttings with variable length, always ensuring three nodes covered by soil, were obtained per genotype. The establishment of cuttings was synchronized placing rooting explants several days in water. These were established in the experimental field of C.I. Turipana of Corporación Colombiana de Investigación Agropecuaria (AGROSAVIA), located in Cereté, department of Córdoba, Colombia. These were cultivated for 90 days before morphological characterization was carried out. Three to five replicates per data point were used, unless stated otherwise.

\section{Morphological characterization}

Selected genotypes were characterized using fortynine parameters from sweet potato descriptors corresponding to a description of an entire plant (Huamán 1991). Sweet potato descriptors contain 47 qualitative 
and three quantitative parameters, which were evaluated 90 days after plant establishment (Table 1).

Image capture

RGB images from leaves and roots for all were taken with a Canon EOS 600D camera configured with similar depth and sensor sensitivity settings for all genotypes. Light, exposition time and the distance between the specimen and the camera were completely controlled among the genotypes evaluated.

Morphometric analysis of leaves

Leaves from apical, subapical and mature shoot segments were dissected and photographed; shape descriptors such as area, perimeter, circularity, roundness and solidity were measured using the ImageJ software on threshold images (http://rsbweb.nih.gov; Abramoff et al. 2004). Circularity is a parameter previously reported for cell shape (Zhang et al. 2011); however, it can easily be adapted for plant organ shape (Table 2).

\section{Colourimetry analysis}

Colourimetric CIE $\mathrm{L} * \mathrm{a} * \mathrm{~b} * \mathrm{C} * \mathrm{~h}$ data was obtained from root flesh in transversal slides employing a PCECSM2 colourimeter with an aperture of $8 \mathrm{~mm}$, and a D65-LED light source. Three roots per plant and five plants were evaluated per point. In leaf and root periderm, the colour determination was carried out in a selected area (ROI) of the RGB images using a colour measurement plug-in in image J. Mean, mode and standard deviation values were obtained (Table 2).

\section{Coverage area estimation}

Coverage area was determined during the 45th day using aerial RGB imaging from experimental plots. Photographs were taken from $3 \mathrm{~m}$ of distance from the soil; green pixels were automatically detected in RGB images and counted by the free software Easy Leaf Area (Easlon and Bloom 2014).

Data analysis

Field descriptions and RGB images-colourimetry were included in the phenotypic diversity estimation.
Initially, databases were independently evaluated considering normality and non-normality assumptions in order to detect atypical data. Subsequently, the relationships between field, colour and morphological traits were evaluated using Spearman's correlations, and the approach of variable clustering was implemented in the ClustofVar library (Chavent et al. 2012).

For individual relationship estimations both Euclidean distances for quantitative traits and Gower distances for qualitative traits implemented in the cluster procedure of the $\mathrm{R}$ package (Maechler et al. 2018) were evaluated. Further, dissimilarity matrices were graphically analyzed using hierarchical clustering. The number of clusters was obtained using Silhouettes (Rousseeuw 1987). Manipulation and pruning of databases, as well as data evaluation and plotting, were performed using the R software.

\section{Results}

Phenotypic diversity estimation by conventional morphological characters from sweet potato descriptors

The morphological characterization of seventy sweet potato accessions collected in the northern coast of Colombia employing forty-nine parameters from sweet potato descriptors (Huamán 1991), revealed two main clusters, which were differentiated by tuberous root formation. In contrast to group B, which exhibited tuberous roots at 90 DAP, group A did not produce tuberous roots during the assessment period, therefore, some characters were not evaluated in group A. Further, group A was comprised of two subgroups, A1 and A3, discriminated mainly by flower characters, i.e. subgroup A3 did not exhibit flowers during the evaluation period. Ten subgroups comprise group B, where subgroups B5 and B8 were clustered due to flower absence at the evaluation period, meanwhile, the rest of this subgroups had already flowered (Fig. 1). Significant differences among groups were found in several conventional characters related to flower, vine colour and roots, and mode values demonstrated that a wide diversity among all groups was not found (Table 3). From 49 parameters evaluated, only 20 showed significant differences, however, the clustering analysis revealed low variability in traits related with flowering and higher diversity in root 
Table 1 Parameters evaluated in morphological descriptors for sweet potato according to Huamán (1991)

\begin{tabular}{|c|c|c|c|c|c|}
\hline & Plant description & & Storage root & & Inflorescence \\
\hline 1 & Mature leaf colour & 1 & Storage root shape & 1 & Flower length $(\mathrm{cm})$ \\
\hline 2 & Immature leaf colour & 2 & Storage root surface defects & 2 & Flower width $(\mathrm{cm})$ \\
\hline 3 & Vine internode length & 3 & Storage root cortex thickness & 3 & Flowering habit \\
\hline 4 & Vine internode diameter & 4 & Predominant skin colour & 4 & Flower colour \\
\hline 5 & Predominant vine colour & 5 & Intensity of predominant skin colour & 5 & Limb shape \\
\hline 6 & Secondary vine colour & 6 & Secondary skin colour & 6 & Equality of sepal length \\
\hline 7 & Vine tip pubescence & 7 & Predominant flesh colour & 7 & Number of sepal veins \\
\hline 8 & Mature leaf shape & 8 & Secondary flesh colour & 8 & Sepal shape \\
\hline 9 & Leaf lobes type & 9 & Distribution of secondary flesh colour & 9 & Sepal apex \\
\hline 10 & Leaf lobes number & 10 & Storage root formation & 10 & Sepal pubescence \\
\hline 11 & Shape of central leaf lobe & 11 & Storage root stalk & 11 & Sepal colour \\
\hline 12 & Mature leaf size & 12 & Number of storage roots per plant & 12 & Stigma colour \\
\hline 13 & Petiole length & 13 & Variability of storage root shape & 13 & Style colour \\
\hline 14 & Petiole pigmentation & 14 & Variability of storage root size & 14 & Stigma exertion \\
\hline 15 & Abaxial leaf vein pigmentation & 15 & Storage root cracking & 15 & Seed capsule set \\
\hline \multirow[t]{3}{*}{16} & Length of the main vines & 16 & Latex production in storage roots & & \\
\hline & & 17 & Oxidation in storage roots & & \\
\hline & & 18 & Days to root formation & & \\
\hline
\end{tabular}

traits. The clusters obtained showed high similarity in several traits among these, showing the usual constraint of conventional morphological characterization that produced data that does not detect phenotypic polymorphisms because the conventional characterization is recorded either visually or manually, or due to limited categorical options. These results showed that the conventional descriptors used had some limitations, especially for colour and shape descriptions, which probably are the most important traits in a specific genotype due to the high diversity observed in these characters.

New approaches introduced to the morphological characterization

Colour and shape parameters were obtained from RGB images. Circularity, aspect ratio, roundness and solidity are shape descriptors based on area, perimeter, major axis, minor axis and convex area (http://rsbweb. nih.gov; Abramoff et al. 2004). Using the concept of circularity as a measurement of shape complexity and based in the relation of area and perimeter (Zhang et al. 2011), and solidity as the relation of area and convex area, differences in leaf shape were consistent among visual differences in terms of lobes number, and lobe length, among others (Fig. 2a, b). Thus, leaves with pronounced lobes were represented by lower circularity and solidity values compared to those observed in leaves with less pronounced lobes; hence, roundness (round) values as a result of area and major axis relation, did not show any conclusive relation with leaf shape complexity. Similarly, other visual characters such as the colour of mature and immature leaves, abaxial vein, root flesh, among others, are subjectively evaluated and mainly based in few categorical options. The establishment of the mean red, green and blue pixel values from RGB images showed an improvement in the discrimination of organ colours that were not detected by visual evaluation (Fig. 2c). This lowcost strategy is widely used for crop monitoring to establish several vegetation indices derived from RGB digital images (Vergara-Díaz et al. 2016). Moreover, mean $R, G, B$ pixel values per se are factors that can consistently be used to quantitatively discriminate sweet potato accessions. This method showed differences in accessions that were described in the same colour category of mature leaf, main abaxial vein and root by morphological descriptors (Fig. 3a-d); furthermore, the distribution of $\mathrm{R}, \mathrm{G}, \mathrm{B}$ pixel values were 
Table 2 Morphometric and colourimetric parameters evaluated in phenotypic characterization of sweet potato accessions

\begin{tabular}{|c|c|c|c|c|c|}
\hline & Colourimeter parameters & & RGB colour description & & Morphometric characters \\
\hline 1 & $\mathrm{~L}$ & 1 & Adaxial 1st leaf red colour value & 1 & Area of the 1st leaf lamina \\
\hline 2 & a & 2 & Adaxial 1st leaf green colour value & 2 & Perimeter of the 1 st leaf lamina \\
\hline 3 & $\mathrm{~b}$ & 3 & Adaxial 1st leaf blue colour value & 3 & Circularity of the 1 st leaf lamina \\
\hline 4 & $\mathrm{c}$ & 4 & Adaxial 5th leaf red colour value & 4 & Area fraction of the 1 st leaf lamina \\
\hline 5 & $\mathrm{~h}$ & 5 & Adaxial 5th leaf green colour value & 5 & Aspect ratio of the 1 st leaf lamina \\
\hline 6 & HL & 6 & Adaxial 5th leaf blue colour value & 6 & Roundness of the 1st leaf lamina \\
\hline 7 & $\mathrm{Ha}$ & 7 & Adaxial 10th leaf red colour value & 7 & Solidity of the 1 st leaf lamina \\
\hline 8 & $\mathrm{Hb}$ & 8 & Adaxial 10th leaf green colour value & 8 & Area of the 5th leaf lamina \\
\hline 9 & WH & 9 & Adaxial 10th leaf blue colour value & 9 & Perimeter of the 5th leaf lamina \\
\hline 10 & WI & 10 & Abaxial 1st leaf red colour value & 10 & Circularity of the 5th leaf lamina \\
\hline 11 & YI & 11 & Abaxial 1st leaf green colour value & 11 & Area fraction of the 5 th leaf lamina \\
\hline 12 & $X$ & 12 & Abaxial 1st leaf blue colour value & 12 & Aspect ratio of the 5th leaf lamina \\
\hline 13 & $\mathrm{Y}$ & 13 & Abaxial 5th leaf red colour value & 13 & Roundness of the 5th leaf lamina \\
\hline \multirow[t]{14}{*}{14} & $\mathrm{Z}$ & 14 & Abaxial 5th leaf green colour value & 14 & Solidity of the 5 th leaf lamina \\
\hline & & 15 & Abaxial 5th leaf blue colour value & 15 & Area of the 10th leaf lamina \\
\hline & & 16 & Abaxial 10th leaf red colour value & 16 & Perimeter of the 10 th leaf lamina \\
\hline & & 17 & Abaxial 10th leaf green colour value & 17 & Circularity of the 10th leaf lamina \\
\hline & & 18 & Abaxial 10th leaf blue colour value & 18 & Area fraction of the 10th leaf lamina \\
\hline & & 19 & Abaxial Midvein red colour value & 19 & Aspect ratio of the 10th leaf lamina \\
\hline & & 20 & Abaxial Midvein green colour value & 20 & Roundness of the 10th leaf lamina \\
\hline & & 21 & Abaxial Midvein blue colour value & 21 & Solidity of the 10th leaf lamina \\
\hline & & 22 & root skin colour red colour value & 22 & petiole length \\
\hline & & 23 & root skin colour green colour value & 23 & Circularity of tuberous root \\
\hline & & 24 & root skin colour blue colour value & 24 & Coverage area \\
\hline & & 25 & root flesh colour red colour value & & \\
\hline & & 26 & root flesh colour green colour value & & \\
\hline & & 27 & root flesh colour blue colour value & & \\
\hline
\end{tabular}

$L$ lightness, $a$ green-red colour component, $b$ blue-yellow colour component, $c$ chroma, $h$ hue angle, $H L$ delta L, $H a$ delta a, $H b$ delta b compared to white standard, $X$ chromaticity in $\mathrm{X}$ axis, $Y$ chromaticity in $\mathrm{Y}$ axis, $Z$ chromaticity in $\mathrm{X}$ axis

not related to all colour categories, confirming its better efficiency to detect phenotypic polymorphisms.

A comparison between morphometric measurements and a set of morphological descriptors for leaf morphs showed an expected negative correlation (Table 4); as central lobe shape, lobe type and lobes number gave more complexity to leaf shape (an increase in a categorical number or the presence of more than one level), circularity values were lower than those observed in low complexity categorical types (Fig. 4a-c). Similarly, solidity exhibited negative correlations with all morphological parameters for leaf shape descriptors, meanwhile, roundness and area showed a negative correlation with central lobe shape, and a positive relationship with mature leaf area, but not with lobe number and type (Table 4).

Potential of including morphometric and colourimetric evaluations to dissect phenotypic polymorphism

Morphometric and colourimetric parameters were evaluated in leaves and roots. Two main groups were obtained from this information where most of the accessions were included in group B, with exception of accession 0515-006 CES which belonged to group A (Fig. 5). Accession 0515-006 CES in contrast to the rest of the evaluated genotypes exhibited the highest $\mathrm{R}$ 


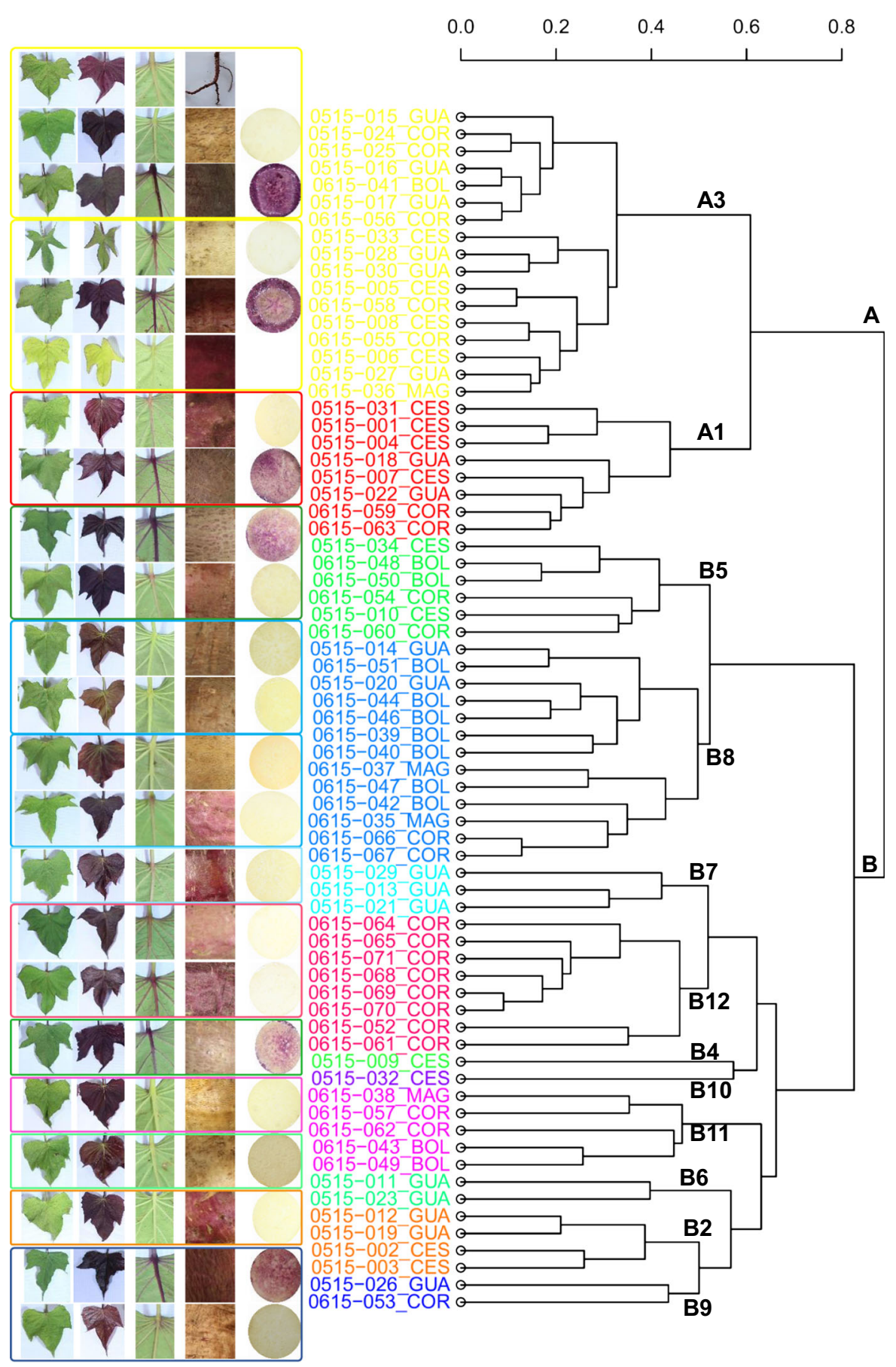

Fig. 1 Cluster analysis to dissect phenotypic diversity using traditional morphological descriptors for sweet potato

and $G$ pixel values in leaves, nonetheless, this accession failed to produce tuberous roots. Differences between accessions were detected by these quantitative parameters, i.e. accessions with less lobed leaves and similar R, G, and B pixel values in above- ground tissue and beige root flesh, comprised subgroups B2 and B7. On the other hand, accessions with beige root flesh and a green or pink main abaxial vein were clustered in groups B3 and B11. This approach allowed discriminating wild-relatives and genotypes 
Table 3 Mean and/or mode values for sweet potato groups for conventional morphological descriptors for which significant $(p<0.0001)$ differences have been found among group means

\begin{tabular}{|c|c|c|c|c|c|c|c|c|c|c|c|c|}
\hline \multirow[t]{2}{*}{ Morphological traits } & \multicolumn{12}{|c|}{ Groups } \\
\hline & $\mathrm{A} 1$ & B2 & A3 & B4 & B5 & B6 & B7 & B8 & B9 & B10 & B11 & B12 \\
\hline Flower length $(\mathrm{cm})$ & 4.2 & 4.2 & & 3.9 & & 4.4 & 4.1 & & 4.2 & 4.9 & 4.3 & 4.3 \\
\hline Flower width $(\mathrm{cm})$ & 3.4 & 3.9 & & 3.9 & & 4.2 & 3.8 & & 3.3 & 4.9 & 3.9 & 3.6 \\
\hline Predominant vine colour & 4 & 3 & 3 & 8 & 7 & 3 & 3 & 1 & 6,7 & 3 & 3 & 3 \\
\hline Flowering habit & 3 & 3 & 0 & 3 & 0 & 5,3 & 3 & 0 & 5 & 3 & 3 & 3 \\
\hline Flower colour & 4 & 4 & & 4 & & 4,2 & 4 & & 4,2 & 4 & 3 & 2 \\
\hline Stigma colour & 1 & 1 & & 1 & & 1 & 1 & & 1 & 1 & 1 & 1 \\
\hline Style colour & 3 & 1 & & 3 & & 3 & 3 & & 3 & 3 & 3 & 3 \\
\hline Stigma exertion & 1 & 1 & & 5 & & 3 & 3 & & 5,1 & 7 & 3 & 3 \\
\hline Storage root surface defects & & 0 & & 0 & 0 & 2,0 & 2 & 2 & 0 & 3 & 2 & 2 \\
\hline Storage root cortex thickness & & 7 & & 9 & 7 & 7,0 & 7 & 7 & 7,9 & 7 & 9 & 3 \\
\hline Predominant skin colour & & 6 & & 6 & 9 & 3,2 & 9 & 5 & 9,5 & 2 & 6 & 6 \\
\hline Secondary skin colour & & 0 & & 1 & 0 & 0 & 0 & 2 & 0 & 6 & 2 & 2 \\
\hline Predominant flesh colour & & 2 & & 0 & 2 & 2 & 2 & 2 & 9,4 & 1 & 2 & 2 \\
\hline Secondary flesh colour & & $0,1,2,4$ & & 0 & 8 & 1 & 3 & 3 & 2 & 0 & 3 & 3 \\
\hline Distribution of secondary flesh colour & & 9 & & 0 & 8 & 3 & 3 & 3 & 9,8 & 0 & 3 & 3 \\
\hline Storage root formation & 0 & 3 & 0 & 3 & 3 & 3 & 3 & 3 & 3 & 5 & 3 & 3 \\
\hline Variability of storage root shape & & 5 & & 3 & 3 & 3,0 & 3 & 5 & 5 & 5 & 3 & 5 \\
\hline Variability of storage root size & & 5 & & 0 & 3 & 3,0 & 3 & 5 & 5 & 5 & 3 & 5 \\
\hline Latex production in storage roots & & 3 & & 0 & 3 & 7,3 & 3 & 3 & 3,5 & 5 & 3 & 3 \\
\hline Oxidation in storage roots & & 3 & & 3 & 5 & 5,3 & 3 & 3 & 3,7 & 3 & 3 & 3 \\
\hline
\end{tabular}

without tuberous roots in subgroup B8; further, this subgroup was related to subgroups B10 and B1 which exhibited white root flesh. Accessions with a purple main abaxial vein were grouped in a single cluster comprised by subgroups B6, B12, B9 and B5; however, only groups B6, B12 and B5 exhibited purple root flesh, and B9 was an accession with beige root flesh (Fig. 5).

The number of significant differences among clusters obtained from conventional data analysed independently ranged from zero (between groups B2 and B7, B2 and B11) to 21 (between groups B3 and B9, A4 and B10), and mainly the differences were established for flower and root traits (Table 5). Otherwise, a range from zero to 23 traits with significant differences among groups was obtained from morpho-colourimetric data; although many groups (24 group comparisons) showed significant differences in more than 15 traits, several groups did not show significant differences in any trait (B1-B8,
$\mathrm{B} 1-\mathrm{B} 10, \mathrm{~B} 2-\mathrm{B} 11, \mathrm{~B} 7-\mathrm{B} 11$ and $\mathrm{B} 8-\mathrm{B} 10)$, and the highest number of traits with significant differences were observed comparing group A4 to the rest, consistently with a clustering analysis and dissimilar to group A4 (Fig. 5). These results showed that the use of morpho-colourimetric data independently to characterize sweet potato can face limitations to discriminate different phenotypes, and should be used as a complementary tool for conventional descriptions.

Cluster analysis using a combined database of conventional descriptors and morpho-colourimetric data produced two main groups (A and B), which were discriminated essentially due to the absence or presence of tuberous roots, respectively (Fig. 6; Table 6). Group A was then divided into subgroups A3 and A4, which were characterized for not having flowers during the evaluation period, and subgroups A5 and A1, which had flowered. Significant differences in colour values of the abaxial midvein, root skin and flesh obtained either by RGB image analysis or by 


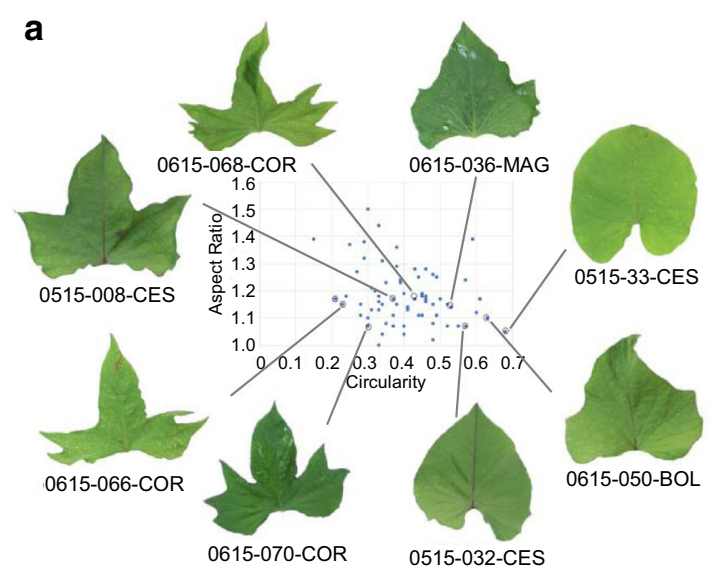

b
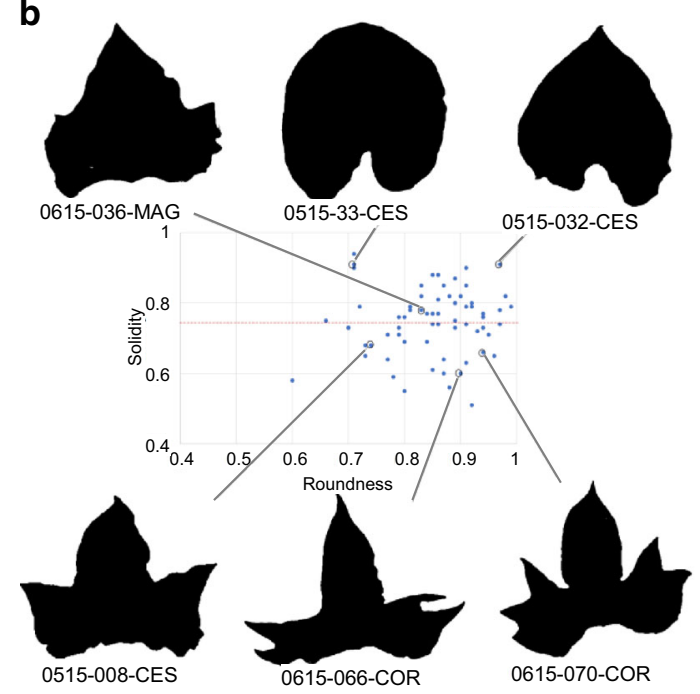

C
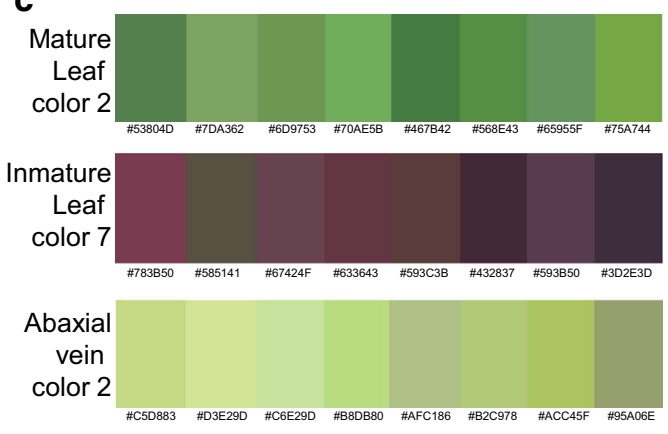

Color codes from RGB pixel values

Fig. 2 Morphometric and colourimetric measurements from RGB images. a Relation of aspect ratio and circularity in leaves of morphotypes. b Relation of solidity and roundness in leaves of morphotypes. c Colour variation established from RGB images in a selected colour category from field descriptors using the colourimeter device and the morphometric description of the 10th leaf lamina were decisive for this clustering formation. Meanwhile subgroups A1 and $\mathrm{A} 3$ showed a higher circularity value but a less lobed leaf, and plants belonging to A4 and A5 subgroups showed more lobed leaves. These differences were not identified employing conventional characterization, and as previously discussed, morpho-colourimetric data independently analysed showed limitations as well. Otherwise, group B was divided into three main subgroups, B10, B8 and B7, which did not show flowers during the evaluation period, but showed differences in colour values of both leaf and root pigmentation; further, plants in subgroup B6 exhibited more lobed leaves (a lower circularity value), lower RGB pixel values and $L^{*} a^{*}$ and $b^{*}$ components indicating the presence of dark pigments in the abaxial midvein and in the root flesh tissue. The subgroup comprised by B12, B11, B9 and B2 showed differences in leaf midvein pigments and most of them exhibited beige colour in root flesh; however, the colour description carrying out RGB images and colourimetry analyses established differences between them (Table 6). These results showed the improvement of including high-performing phenomics methods to characterize sweet potato accessions; moreover, the quantitative colour description demonstrated to be a useful tool to discriminate phenotypes, which is not always possible when using conventional descriptors.

The comparison of individual and combined analyses using conventional and morpho-colourimetric characterization data showed potential to describe plant diversity (Tables 7,8 ). A pairwise comparison analysis revealed the potential of each method to discriminate groups by counting traits with significant differences among sweet potato cluster means. In this sense, $43 \%$ of the conventional and morpho-colourimetric traits showed significant differences among groups obtained through field data analyses, meanwhile, $47.8 \%$ of the traits were significant among groups obtained using morpho-colourimetric data. The highest percentage (55.6\%) of conventional and morpho-colourimetric traits with significant differences among groups was obtained from the combined database used (i.e. including conventional and morpho-colourimetric data). These results confirmed the improvement of the standard characterization to estimate phenotypic plant diversity by complementing these with morpho-colourimetric parameters, which 
a

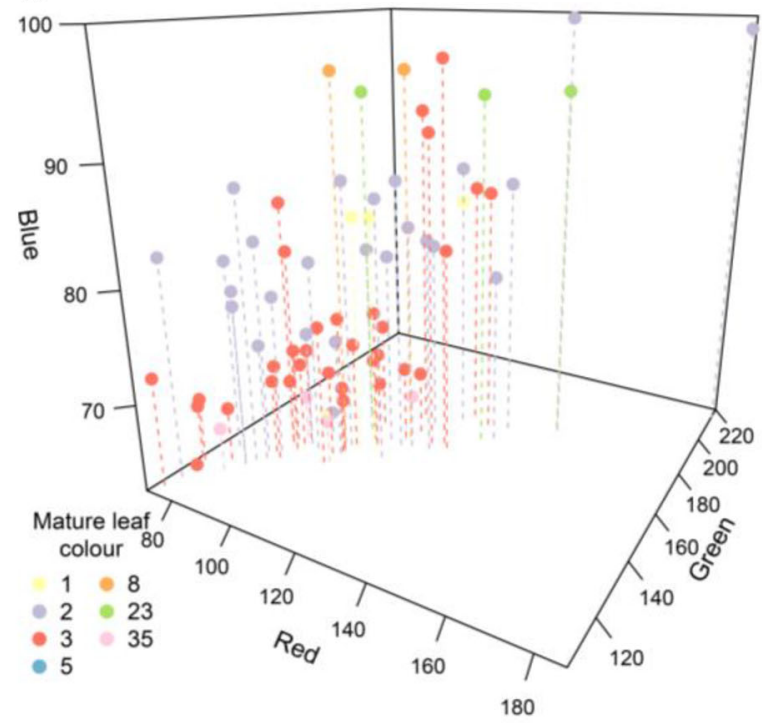

C

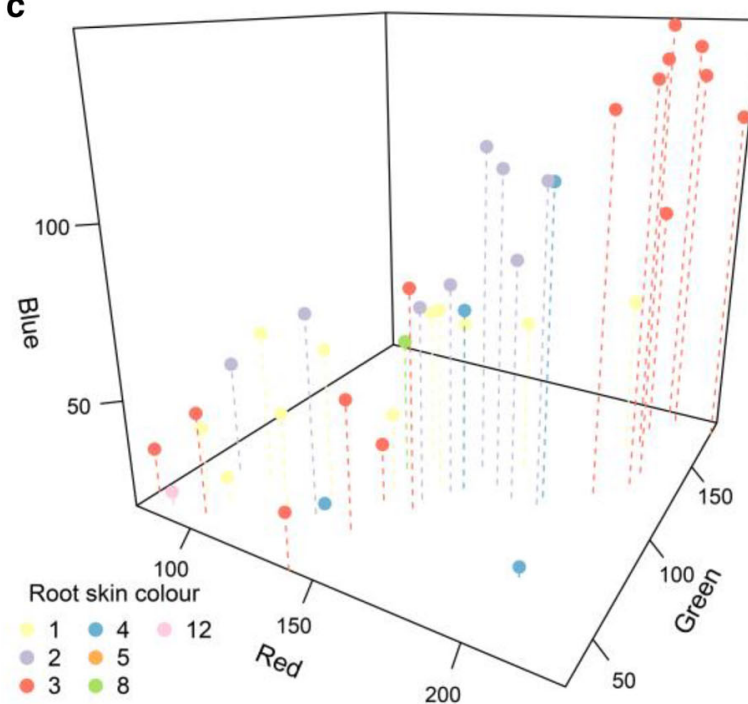

Fig. 3 Colourimetric measurements from RGB images and their relation with field descriptors. Variations of red, green and blue pixel values according to visual descriptions of mature leaf

combined data from RGB images and colour values obtained with a manual colourimeter device. The combined analysis using conventional and morphocolourimetric data showed a range from zero (only groups 11 and 12) to 33 traits (groups 4 and 9) with significant differences among pairwise comparisons; in these, 40 group comparisons showed more than 15 traits with significant differences between the groups

\section{b}

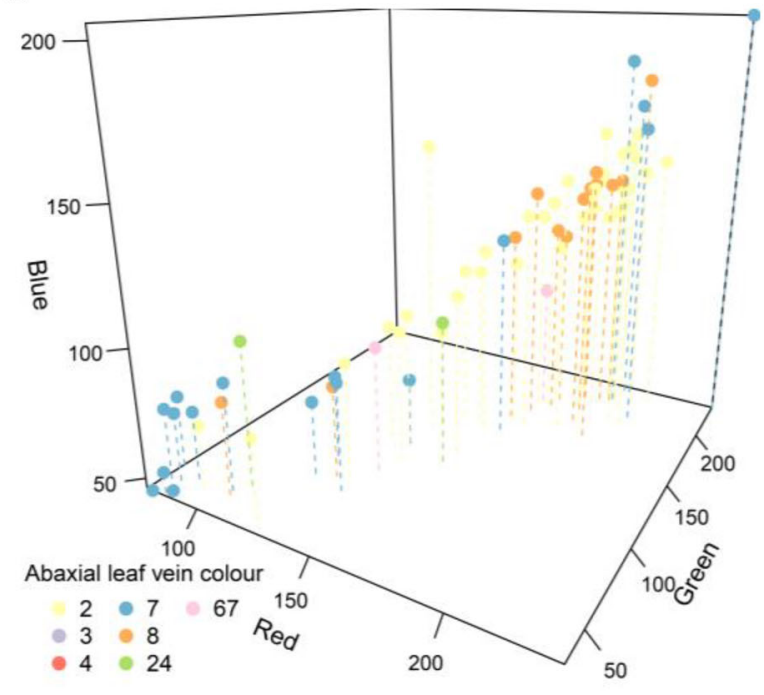

d

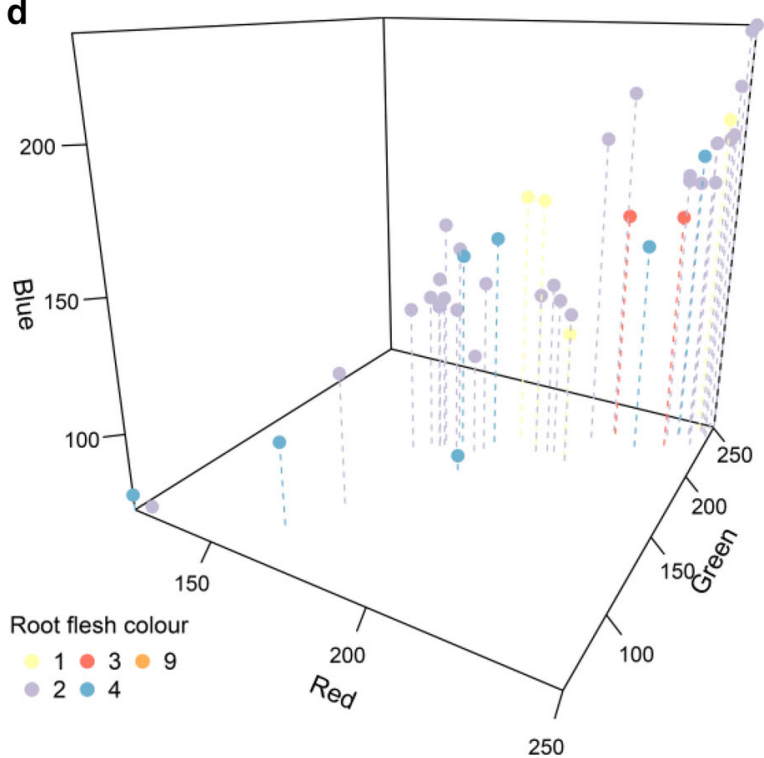

colour (a), main abaxial vein (b), external root colour by root skin (c) and root flesh (d) colour categories

compared (Table 9). These differences among groups were related mainly with colour values obtained by either RGB analysis or using the manual colourimeter device, the coverage area and from the conventional characterization, i.e. traits related with flowering and root. 
Table 4 Spearman's correlation between morphometric parameters measured using Image J and field descriptors

\begin{tabular}{lllll}
\hline Morphometric parameter & Central lobe shape & Lobe number & Lobe type & Mature leaf size \\
\hline Circularity of the 10th leaf lamina & $-0.569^{* *}$ & $-0.472^{* *}$ & $-0.417^{* *}$ & $-0.31^{*}$ \\
Solidity of the 10th leaf lamina & $-0.618^{* *}$ & $-0.428^{* *}$ & $-0.435^{* *}$ & $-0.275^{*}$ \\
Roundness of the 10th leaf lamina & $-0.379^{*}$ & $\mathrm{~ns}$ & $\mathrm{~ns}$ & $0.244^{*}$ \\
Area of the 10th leaf lamina & $-0.237^{*}$ & $\mathrm{~ns}$ & $\mathrm{~ns}$ & $0.33^{* *}$ \\
\hline
\end{tabular}

$n s$ no significant differences

$* * p<0.001 ; * p<0.05$

\section{Discussion}

Constraints of conventional morphological characterization in sweet potato

Morphological characterizations have been used as a first step in the assessment of plant diversity, but in sweet potato, several studies have used this approach to quantify diversity in a specific geographical area to eliminate duplicated accessions in germplasm banks, and to produce important information for sweet potato breeding (Veasey et al. 2007; Koussao et al. 2014). Although the importance of this characterization will never be replaced by any other approach, the results can be improved by quantifying all parameters to be measured. In this study, from the 49 evaluated parameters, only 20 showed significant differences; furthermore, the clustering analysis revealed low variability in traits related with flowering and higher diversity in root traits. The clusters obtained showed high similarity exhibiting the usual constraints of the conventional morphological characterization by producing data that does not detect phenotypic polymorphisms. This is because the conventional characterization is recorded either visually or manually, or due to the limited categorical options that may exist. When using conventional descriptors, some limitations, especially for colour and shape descriptions, were observed, which probably are the most important traits in a specific genotype due to the high diversity observed in these characters. The morphological characterization has to be improved in order to avoid a time-consuming process and reduce the chance of errors in trait measurements (Kumar et al. 2015). Several studies showed the limitations of standard morphological characterizations, especially to describe fruit shape in scarlet and gboma eggplants complexes (Plazas et al. 2014; Kaushik et al.; 2016), in tomato (Figàs et al. 2015) and in papaya (Marmolejo et al. 2017). Mainly, dissection of phenotypic polymorphisms has been limited due to the establishment of categorical scales that do not allow distinguishing specimens with differences that are not visible in a recognized category. Similarly, colour description is limited not only due to the categorical scale used, but it is also affected in the field (sunlight) by environmental conditions as well as by human perception. To improve the phenotypic characterization, approaches to morphometric and colourimetric characterizations should be included to dissect differences among genotypes in high diversity traits.

New approaches for morphological characterization and its potential to dissect phenotypic polymorphisms in sweet potato

Colour and shape parameters were obtained from RGB images. Circularity, aspect ratio, roundness and solidity were shape descriptors considered in this study to quantitatively describe leaf shape among sweet potato accessions. Using the concept of circularity as a measurement of shape complexity based in the relation of area and perimeter (Zhang et al. 2011), and solidity as a relation of the area and the convex area, differences in leaf shape were consistent among visual differences in terms of lobe number, lobe length, among others. Thus, leaves with pronounced lobes were represented by lower circularity and solidity values compared to those observed in leaves with less pronounced lobes; hence, roundness (round) values as a result of the relation between area and major axis did not show any conclusive relation with leaf shape complexity. In angiosperms, leaves are highly diverse in terms of size and shape; leaf shape is 


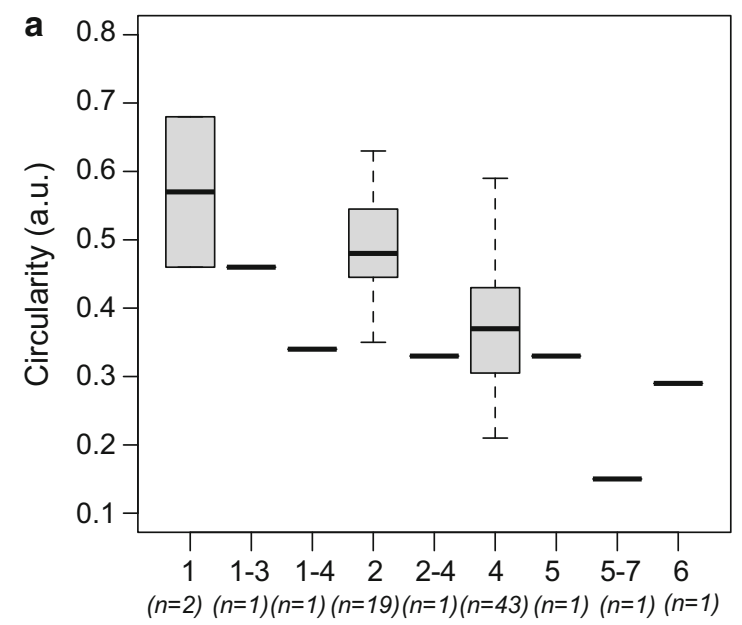

Central lobe shape
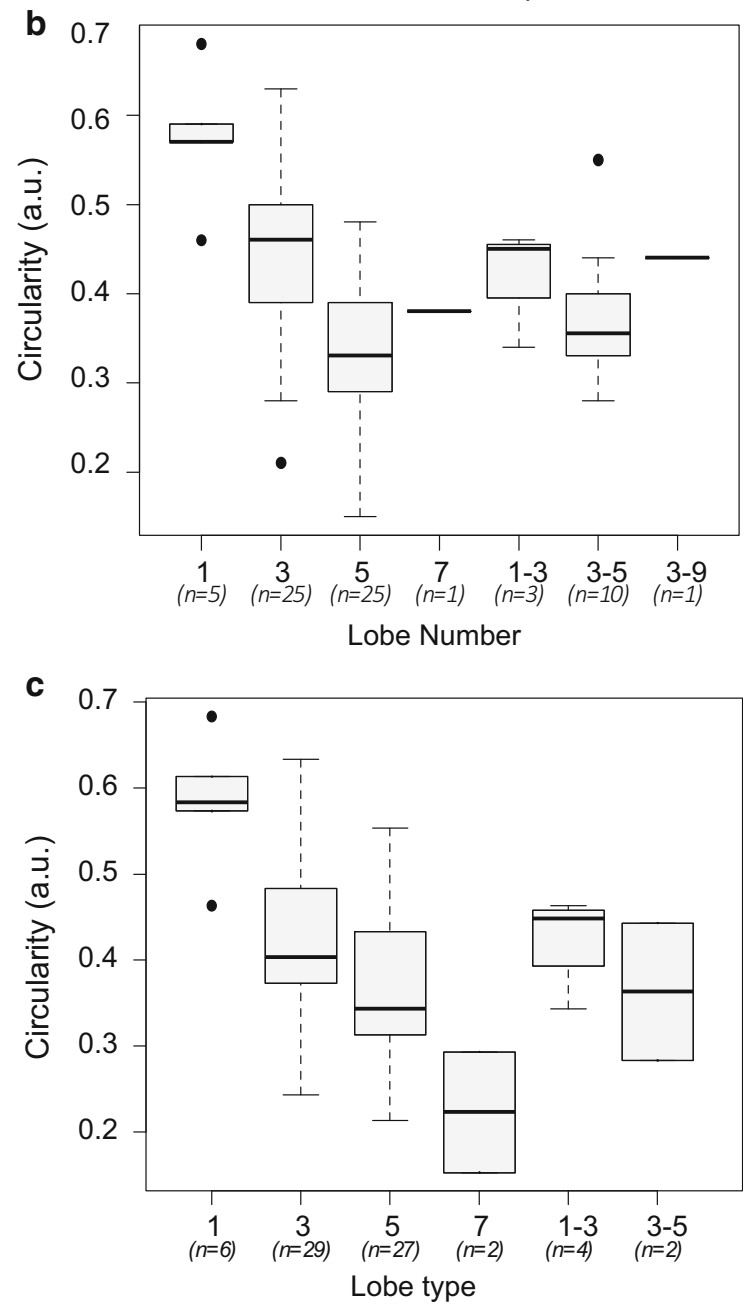

a character that is less affected across environments or biomes compared to size; then, its functional
४Fig. 4 Morphometric measurements from RGB images and their relation with field descriptors. Circularity variation according to central lobe shape (a), lobe number (b) and lobe type (c) categories

significance still remains under discussion (Nicotra et al. 2011). Although the International Board for Plant Genetic Resources (IBPGR) recommended the evaluation of mature leaf shape, the general outline of the leaf, types of leaf lobes, leaf lobe number and the shape of the central leaf lobe as morphological characters for sweet potato leaf characterization (Huamán 1991). Nonetheless, the use of these is limited to categorical parameters, which in some cases, did not allow discriminating leaf morphs. In barley, a minimum set of morphological descriptors showed poor level of congruence regarding the diversity observed in important genetic characters (Cross et al. 1992), and the morphometric approaches for leaf shape characterization showed to be an accurate phenotypic analysis that has been used to describe quantitatively diverse patterns of blade outgrowth, hirsuteness and venation patterning (Chitwood et al. 2013; 2014; Lockhart 2013). Similarly, other visual characters such as the colour of mature and immature leaves, abaxial vein, root flesh, etc., are subjectively evaluated and mainly based in few categorical options. The establishment of mean red, green and blue pixel values from RGB images showed to improve the discrimination of organ colours that were not detected through the visual evaluation. This low-cost strategy has been widely used for crop monitoring by establishing several vegetation indices derived from RGB digital images (Vergara-Díaz et al. 2016); the mean R, G, and B pixel values per se were factors used to quantitatively discriminate sweet potato accessions. This method showed differences in accessions that were described in the same colour category of mature leaf, main abaxial vein and root by morphological descriptors. Nevertheless, the distribution of R, G, and B pixel values were not related to all colour categories, confirming its better efficiency to detect phenotypic polymorphisms.

A comparison between morphometric measurements and a set of morphological descriptors for leaf morphs showed an expected negative correlation, as central lobe shape, lobe type and lobes number give more complexity to leaf shape (an increase in the 


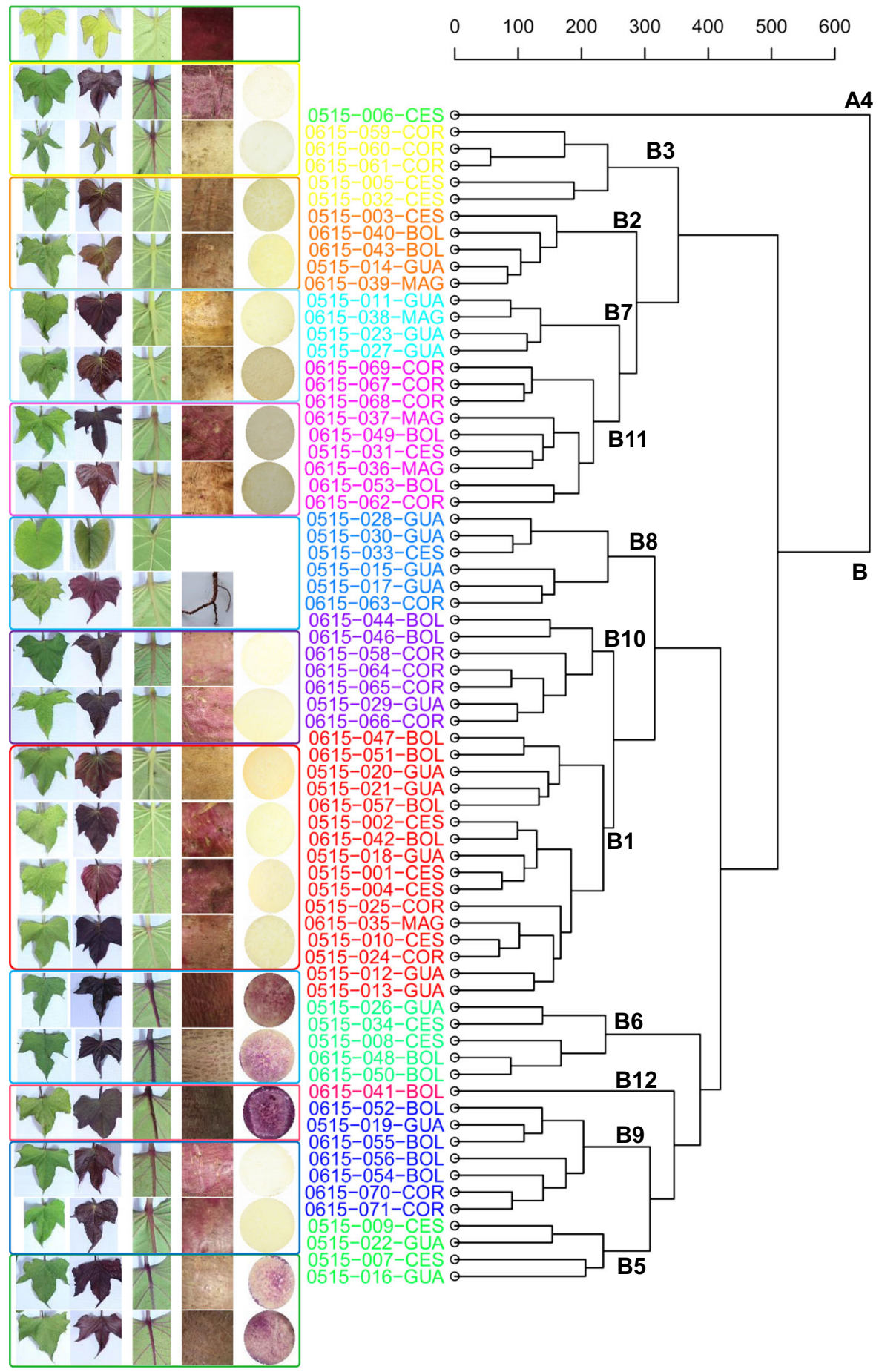

Fig. 5 Phenotypic diversity estimation obtained by morphometric and colourimetric approaches for sweet potato

categorical number or presence of more than one level). Morphometric parameters were previously reported as useful tools to capture leaf shape information and their accuracy to improve morphological characterizations and contribute effectively with accurate data in genetic studies (Chitwood et al. 
Table 5 Number of significant $(p<0.05)$ differences among sweet potato group means for 48 conventional descriptors and 64 morpho-colourimetric characters

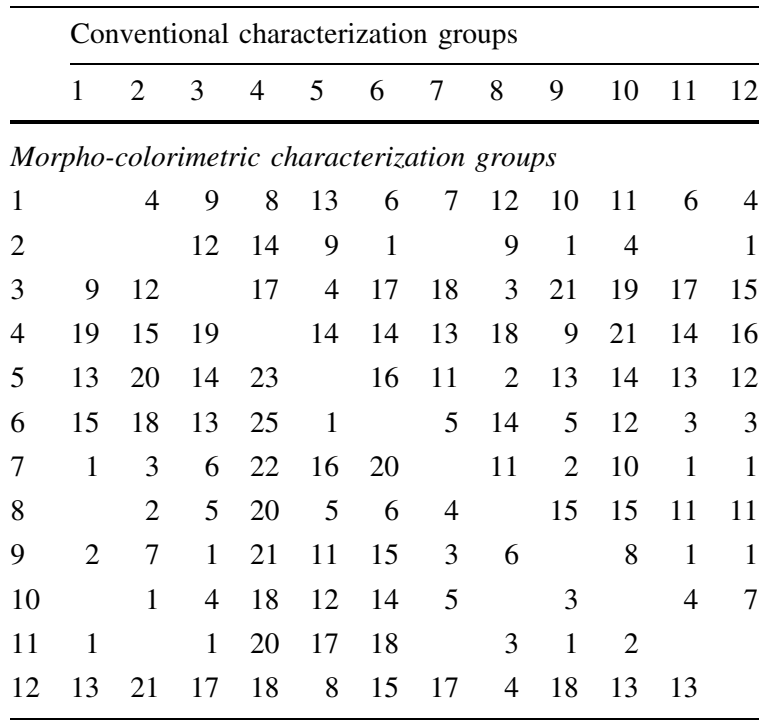

2013). This method based on contour and on landmark analyses previously demonstrated its success quantifying leaf shape and leaf margin, and contributed to a better understanding of gene functions (Biot et al. 2016) and natural diversity determinations (Nicotra et al. 2011). Combined analyses showed the power of including quantitative data in morphological characterizations to efficiently discriminate sweet potato accessions. The methods used in this study were based in shape measurements and complexity, which respond to genotype and leaf development, and therefore, these produced several morphometric and ontogenetic parameters in sweet potato. Otherwise, colour description by quantifying pixel values is a method that guarantees colour differentiation in plants (Kendal et al. 2013). Several compounds in plants dissipate absorbed light and reflect light visible as colour. Then, the colours are the result of reflected or transmitted light of varying wavelengths between 380 and $730 \mathrm{~nm}$, or a mix of residual wavelengths (Mlodzinska 2009; Tanaka et al. 2008). The results of this study showed the potential of RGB images capturing eye-catching plant pigments, and the estimation of the pixel values described quantitatively sweet potato phenotypic diversity in terms of plant organ pigmentation. Further, plant diversity considering pigmentation patterns is a result of spatial distribution and accumulation of coloured compounds, especially anthocyanins, carotenoids, flavonoids, betalains, etc. (Tanaka et al. 2008; Albert and Davies 2014). Then, physiological and genetic processes determine the pigmentation patterns among phenotypes, and possibly, genotypes; on the other hand, the quantitative evaluation improved the discrimination between analysed specimens.

The number of significant differences among clusters obtained from conventional data analysed independently ranged from zero to 21 , and mainly the differences were established for flower and root traits. Otherwise, a range from zero to 23 traits with significant differences among groups was obtained from morpho-colourimetric data; although many groups showed significant differences in more than 15 traits, several groups did not show significant differences in any trait. These results showed that the use of morpho-colourimetric data independently to characterize sweet potato can face limitations to discriminate different phenotypes, and should be used as a complementary tool to the conventional description.

Cluster analysis using a combined database of conventional descriptors and morpho-colourimetric data produced two main groups. Significant differences in colour values of the abaxial midvein, root skin and flesh obtained either by RGB image analysis or employing a colourimeter device and morphometric description of the 10th leaf lamina were decisive for this clustering formation, together with flower and root parameters from the conventional description; meanwhile, circularity, colour values from RGB images and $\mathrm{L}^{*} \mathrm{a}^{*}$, and $\mathrm{b}^{*}$ components, indicate the presence of pigments in the abaxial midvein and in root flesh tissue of both leaf and root pigmentation that defined some subgroups. These differences were not identified by the conventional characterization, and as previously discussed, morpho-colourimetric data independently analysed showed limitations as well. This analysis consistently confirmed the improvement of including high-performance phenomics methods to characterize sweet potato accessions; the quantitative colour description demonstrated to be a useful tool to discriminate phenotypes, which is not always possible using conventional descriptors; then, colour parameters obtained by the analysis of RGB images or employing colorimetry, improve the assessment of pigment distribution and accumulation, that are the 
Fig. 6 Phenotypic diversity estimation obtained by traditional morphological descriptors and improved by morphometric and colourimetric approaches for sweet potato.

a Comparison of cluster assignation of genotypes through individual and combined analyses.

b Dendrogram obtained using a combined analysis a

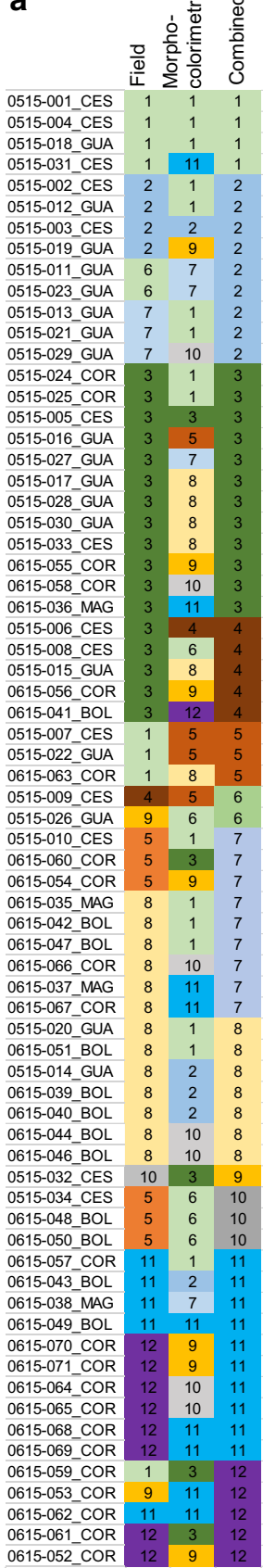

0615-052_COR
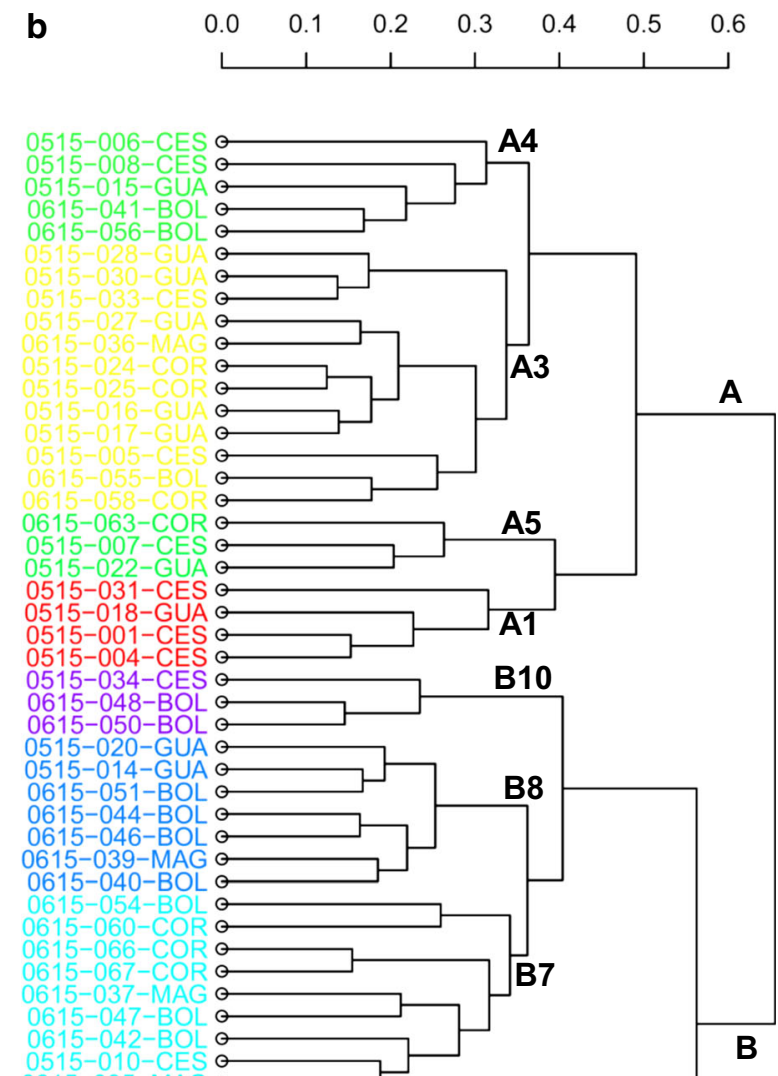

0515-009-CES o B B6

$0515-026-G \cup A$

0615-052-BOL

0615-059-COR

0615-061-COR

0615-053-BOL

0615-062-COR

0615-064-COR Q

$0615-068-C O R$ Q

0615-071-COR

0615-065-COR Q

0615-069-COR

$0615-070-\mathrm{COR}$

0615-043-BOL

0615-049-BOL

0615-038-MAG

0615-057-BOL

0515-002-CES

0515-003-CES

0515-011-GUA

0515-023-GUA

0515-013-GUA

0515-021-GUA

0515-012-GUA Q

0515-019-GUA Q

demonstrated to be an adequate method to improve in $10 \%$ the accuracy for the description of this organ (Kadir et al. 2011). In addition, $\mathrm{L}^{*}, \mathrm{a}^{*}$ and $\mathrm{b}^{*}$ components have been successfully used for evaluation and plant recognition, even used in true-colour sensors that are able to detect weeds from plant coverage (Schmittmann and Schulze Lammers 2017). 
Table 6 Mean and/or mode values for sweet potato groups for conventional descriptors and morpho-colourimetric parameters for which significant $(p<0.0001)$ differences have been found among group means

\begin{tabular}{|c|c|c|c|c|c|c|c|c|c|c|c|c|}
\hline Characters & A1 & $\mathrm{B} 2$ & A3 & A4 & A5 & B6 & B7 & B8 & B9 & B10 & B11 & B12 \\
\hline Circularity of the 10th leaf lamina & 0.455 & 0.459 & 0.447 & 0.296 & 0.387 & 0.295 & 0.371 & 0.383 & 0.570 & 0.520 & 0.363 & 0.400 \\
\hline Abaxial midvein red colour value & 189.3 & 194.0 & 167.9 & 145.6 & 121.0 & 94.5 & 169.8 & 190.3 & 75.0 & 80.8 & 160.6 & 146.2 \\
\hline $\begin{array}{l}\text { Abaxial midvein green colour } \\
\text { value }\end{array}$ & 184.0 & 191.8 & 175.6 & 121.6 & 88.7 & 50.5 & 156.0 & 216.3 & 54.0 & 41.3 & 157.0 & 123.2 \\
\hline Abaxial midvein blue colour value & 138.3 & 155.6 & 124.4 & 100.6 & 90.3 & 87.5 & 125.9 & 130.0 & 74.0 & 62.5 & 115.8 & 100.0 \\
\hline Days to root formation & 120.0 & 90.0 & $0-150$ & $0-150$ & 120 & 90 & 90 & 90 & 90 & 90 & 90 & 90 \\
\hline Root skin colour red colour value & 148.3 & 165.9 & 147.3 & 119.4 & 126.3 & 120.0 & 169.6 & 130.3 & 220.0 & 121.3 & 174.6 & 204.6 \\
\hline Root flesh colour red colour value & 246.0 & 226.9 & 226.3 & 157.3 & 184.5 & 171.5 & 220.0 & 217.3 & 203.0 & 164.0 & 197.2 & 225.4 \\
\hline $\begin{array}{l}\text { Root flesh colour green colour } \\
\text { value }\end{array}$ & 237.5 & 218.6 & 225.3 & 124.0 & 132.5 & 129.5 & 209.0 & 200.0 & 194.0 & 112.5 & 192.0 & 224.8 \\
\hline $\mathrm{L}$ & 84.4 & 86.6 & 86.5 & 50.8 & 52.1 & 59.8 & 87.5 & 85.3 & 86.4 & 66.6 & 88.7 & 88.7 \\
\hline $\mathrm{a}$ & 4.9 & 2.6 & 2.6 & 24.4 & 25.2 & 23.0 & 2.6 & 4.4 & 0.3 & 16.8 & 1.3 & 1.5 \\
\hline $\mathrm{b}$ & 27.4 & 26.1 & 20.5 & 3.6 & 3.8 & 4.9 & 23.6 & 31.6 & 12.1 & 6.3 & 20.5 & 14.6 \\
\hline $\mathrm{c}$ & 28.0 & 26.3 & 20.8 & 25.3 & 25.8 & 24.0 & 23.8 & 31.9 & 12.1 & 20.5 & 20.5 & 14.7 \\
\hline HL & 80.5 & 83.2 & 83.1 & 43.8 & 45.1 & 53.0 & 84.2 & 81.6 & 82.9 & 60.6 & 85.7 & 85.8 \\
\hline $\mathrm{Ha}$ & 4.6 & 2.4 & 2.5 & 20.1 & 20.9 & 19.8 & 2.4 & 4.2 & 0.3 & 14.5 & 1.3 & 1.4 \\
\hline $\mathrm{Hb}$ & 19.7 & 19.3 & 15.4 & 2.3 & 2.6 & 3.5 & 17.7 & 22.3 & 9.7 & 4.8 & 15.8 & 11.6 \\
\hline WH & 67.9 & 70.5 & 75.0 & 44.6 & 45.5 & 53.2 & 73.0 & 64.8 & 81.7 & 60.7 & 76.5 & 81.5 \\
\hline WI & 39.9 & 43.8 & 49.0 & 18.6 & 19.6 & 26.2 & 47.4 & 37.8 & 56.3 & 34.1 & 52.1 & 58.1 \\
\hline YI & 54.4 & 49.4 & 40.3 & 44.9 & 46.4 & 41.5 & 45.1 & 59.6 & 24.1 & 35.4 & 38.7 & 29.0 \\
\hline$X$ & 63.7 & 66.8 & 66.6 & 23.4 & 25.0 & 33.0 & 68.5 & 65.1 & 65.3 & 41.0 & 70.3 & 70.5 \\
\hline $\mathrm{Y}$ & 65.0 & 69.2 & 69.1 & 19.5 & 20.7 & 28.6 & 71.0 & 66.7 & 68.7 & 38.7 & 73.5 & 73.6 \\
\hline $\mathrm{Z}$ & 41.9 & 46.1 & 51.7 & 18.9 & 20.0 & 27.1 & 50.0 & 39.6 & 59.6 & 35.6 & 55.1 & 61.5 \\
\hline Abaxial leaf vein pigmentation & 7 & 7 & 2 & 8 & 6.7 .8 & 8 & 7 & 2 & 8 & 8 & 2 & 8 \\
\hline Coverage area & 43.1 & 34.0 & 15.0 & 17.5 & 19.3 & 35.7 & 15.3 & 42.1 & 85.2 & 39.5 & 27.0 & 15.2 \\
\hline Flower length & 4.3 & 4.3 & & & 4.1 & 4.2 & & & 5.0 & 1.2 & 4.4 & 4.1 \\
\hline Flower width & 3.7 & 4.0 & & & 3.2 & 3.5 & & & 4.7 & 1.2 & 3.9 & 3.3 \\
\hline Predominant vine colour & 3 & 3 & 3 & 6 & 6.7 .8 & 6.8 & 3 & 1 & 3 & 8 & 3 & 6 \\
\hline Flowering habit & 3 & 3 & 0 & 0 & 3 & 3.5 & 0 & 0 & 3 & 0 & 3 & 3 \\
\hline Flower colour & 4 & 4 & & & 4 & 4 & & & 4 & & 3 & 2 \\
\hline Limb shape & 7 & 7 & & & 3 & 3 & & & 7 & & 7 & 7 \\
\hline Equality of sepal length & 2 & 2 & & & 2 & 2 & & & 2 & & 2 & 2 \\
\hline Number of sepal veins & 1 & 1 & & & 1 & 1 & & & 1 & & 1 & 1 \\
\hline Sepal shape & 9 & 9 & & & 9 & 3.9 & & & 5 & & 5 & 9 \\
\hline Sepal apex & 5 & 5 & & & 5 & 1.5 & & & 5 & & 5 & 5 \\
\hline Stigma colour & 1 & 1 & & & 1 & 1 & & & 1 & & 1 & 1 \\
\hline Style colour & 1 & 3 & & & 3 & 3 & & & 3 & & 3 & 3 \\
\hline Stigma exertion & 1 & 3 & & & 3 & 5 & & & 7 & & 3 & 3 \\
\hline Storage root surface defects & & 2 & & & & 0 & 2 & 2 & 3 & 0 & 2 & 0 \\
\hline Storage root cortex thickness & & 7 & & & & 9.7 & 3 & 7 & 7 & 7 & 3 & 7 \\
\hline Predominant skin colour & & 9 & & & & 6.9 & 6 & 5 & 2 & 9 & 6 & 9 \\
\hline Secondary skin colour & & 0 & & & & 0.1 & 2 & 2 & 6 & 0 & 2 & 0 \\
\hline Predominant flesh colour & & 2 & & & & 0.9 & 2 & 2 & 1 & 2 & 2 & 1 \\
\hline Secondary flesh colour & & 1 & & & & 0.2 & 1 & 2 & 0 & 8 & 3 & 2 \\
\hline
\end{tabular}


Table 6 continued

\begin{tabular}{|c|c|c|c|c|c|c|c|c|c|c|c|c|}
\hline Characters & A1 & B2 & A3 & A4 & A5 & B6 & B7 & $\mathrm{B} 8$ & B9 & $\mathrm{B} 10$ & B11 & B12 \\
\hline $\begin{array}{l}\text { Distribution of secondary flesh } \\
\text { colour }\end{array}$ & & 3 & & & & 0.9 & 3 & 3 & 0 & 8 & 3 & 8 \\
\hline Storage root formation & 0 & 3 & 0 & 0 & 0 & 3 & 3 & 3 & 5 & 3 & 3 & 3 \\
\hline Number of storage roots per plant & & 1 & & & & 0.1 & 1 & 0 & 3 & 1 & 2 & 1 \\
\hline Variability of storage root shape & & 3 & & & & 3.5 & 3 & 5 & 5 & 5 & 5 & 5 \\
\hline Variability of storage root size & & 3 & & & & 0.5 & 3 & 0 & 5 & 5 & 5 & 5 \\
\hline Latex production in storage roots & & 3 & & & & 0.3 & 3 & 3 & 5 & 5 & 3 & 3 \\
\hline Oxidation in storage roots & & 3 & & & & 3 & 3 & 3 & 3 & 3 & 3 & 3 \\
\hline
\end{tabular}

$L$ lightness, $a$ green-red colour component, $b$ blue-yellow colour component, $c$ chroma, $h$ hue angle, $H L$ delta L, $H a$ delta a, $H b$ delta b compared to white standard, $X$ chromaticity in $\mathrm{X}$ axis, $Y$ chromaticity in $\mathrm{Y}$ axis, $Z$ chromaticity in $\mathrm{X}$ axis

$*$, **, ***Significant differences at $p<0.05,0.001,0.0001$, respectively

Similarly, this method has been used to improve the characterization of fruits or food quality in pumpkins and in squash; strong correlations were found between colour values $\mathrm{a}^{*}$ and total carotenoids, and between colour value $b^{*}$ and Chroma with lutein (Itle and Kabelka 2009). In tomato, colour changes throughout tomato ripening were the result of significant changes in the values of $\mathrm{L}^{*}, \mathrm{a}^{*}$ and $\mathrm{b}^{*}$ (Lopez and Gomez 2004); some of these colour changes are not detectable by visual colour classification, then, the potential to include colour indices in root skin and flesh in sweet potato accessions improved the conventional characterization. Adaptation of the Easy Leaf Area software (Easlon and Bloom 2014) to estimate coverage area in the field was a tool to quantify the potential of sweet potato accessions to produce and extend vines during their vegetative growth; moreover, it was a trait that showed significant differences in groups comprised by the combined analysis.

Consistent with previous studies, this study showed the improvement in morphological characterization by including phenomics methods (Plazas et al. 2014). The potential use of phenomics in fruit shape description in tomato and eggplant has also been demonstrated (Brewer et al. 2006; Plazas et al. 2014), and its subsequent use in plant breeding (Kaushik et al. 2016). In accordance with our results, quantification of leaf shape in barley (Chitwood et al. 2013, 2014; Lockhart 2013), olive leaves and fruits (Blazakis et al. 2017), and legume leaves (Liao et al. 2017), using geometric estimations allowed comparing and classifying differences among organ shapes that are not perceptible using conventional descriptors, and improving then the accuracy of plant descriptions. In sweet potato, the results showed that morphometric parameters should be included in morphological characterizations, and its potential is promising in physiological and genetic association studies. Low-cost methods using RGB images to estimate colour pixel values, morphometric parameters and coverage area in the field, are tools that improve the discrimination between different sweet potato accessions; in addition, these results showed the applicability of free-software that can easily be adapted for evaluation in the field or in the laboratory, consistent with the observations and estimations obtained by Blazakis et al. (2017).

\section{Conclusion}

Conventional description using categorical parameters faced a constraint to dissect sweet potato diversity in terms of plant pigmentation, organ shape and efficiency in vegetative growth; the inclusion of colour pixel values or indices, morphometric parameters and coverage area estimated by morphometric-colourimetric tools improved the phenotypic characterization of sweet potato and allowed finding differences that were not previously detected. 
Table 7 Morpho-colourimetric parameters with significant differences among means for sweet potato groups obtained in individual and combined analyses

\begin{tabular}{|c|c|c|c|}
\hline & Field Characterization & Morpho-colorimetric characterization & Combined analysis \\
\hline Perimeter of the 1 st leaf lamina & & $*$ & \\
\hline Perimeter of the 5th leaf lamina & & $* *$ & \\
\hline Aspect ratio of the 5th leaf lamina & & $* * *$ & \\
\hline Roundness of the 5th leaf lamina & $*$ & $* *$ & $*$ \\
\hline Perimeter of the 10th leaf lamina & & $* *$ & \\
\hline Solidity of the 10th leaf lamina & & $*$ & \\
\hline Solidity of the 1st leaf lamina & $*$ & & \\
\hline Solidity of the 5 th leaf lamina & $* * *$ & & * \\
\hline Circularity of the 10th leaf lamina & & & $*$ \\
\hline Roundness of the 10th leaf lamina & & & $*$ \\
\hline Adaxial 1 st leaf red colour value & & $* *$ & $*$ \\
\hline Adaxial 1st leaf green colour value & & $* * *$ & \\
\hline Adaxial 1st leaf blue colour value & & & $*$ \\
\hline Adaxial 5th leaf red colour value & & $* * *$ & $*$ \\
\hline Adaxial 5th leaf green colour value & & $* * *$ & $*$ \\
\hline Adaxial 5th leaf blue colour value & & $*$ & \\
\hline Adaxial 10th leaf red colour value & & $* * *$ & \\
\hline Adaxial 10th leaf green colour value & & $*$ & \\
\hline Adaxial 10th leaf blue colour value & & $*$ & $*$ \\
\hline Abaxial 1st leaf red colour value & & $* * *$ & \\
\hline Abaxial 1st leaf green colour value & & $* * *$ & \\
\hline Abaxial 1st leaf blue colour value & & $* * *$ & \\
\hline Abaxial 5th leaf red colour value & & $* *$ & $*$ \\
\hline Abaxial 5th leaf green colour value & & $* * *$ & * \\
\hline Abaxial 5th leaf blue colour value & & $*$ & $*$ \\
\hline Abaxial 10th leaf red colour value & & $* *$ & \\
\hline Abaxial 10th leaf green colour value & & $* *$ & \\
\hline Abaxial 10th leaf blue colour value & & $*$ & \\
\hline Abaxial midvein red colour value & $* *$ & $* * *$ & $* * *$ \\
\hline Abaxial midvein green colour value & $* * *$ & $* * *$ & $* * *$ \\
\hline Abaxial midvein blue colour value & & $* * *$ & $* *$ \\
\hline Root skin colour red colour value & & $* * *$ & $* *$ \\
\hline Root skin colour green colour value & $*$ & $* * *$ & \\
\hline Root skin colour blue colour value & $*$ & $* * *$ & $*$ \\
\hline Root flesh colour red colour value & & $* * *$ & $* *$ \\
\hline Root flesh colour green colour value & & $* * *$ & $* * *$ \\
\hline Root flesh colour blue colour value & & $* * *$ & $*$ \\
\hline $\mathrm{L}$ & $*$ & $* * *$ & $* * *$ \\
\hline $\mathrm{a}$ & $*$ & $* * *$ & $* * *$ \\
\hline $\mathrm{b}$ & $* *$ & $* * *$ & $* * *$ \\
\hline $\mathrm{c}$ & $* *$ & $* * *$ & $* * *$ \\
\hline $\mathrm{h}$ & $*$ & $* * *$ & $*$ \\
\hline HL & & $* * *$ & $* * *$ \\
\hline $\mathrm{Ha}$ & $*$ & $* * *$ & $* * *$ \\
\hline
\end{tabular}


Table 7 continued

\begin{tabular}{llll}
\hline & Field Characterization & Morpho-colorimetric characterization & Combined analysis \\
\hline $\mathrm{Hb}$ & $* *$ & $* * *$ & $* * *$ \\
$\mathrm{WH}$ & & $* * *$ & $* * *$ \\
$\mathrm{WI}$ & $*$ & $* * *$ & $* * *$ \\
$\mathrm{YI}$ & $* *$ & $* * *$ & $* * *$ \\
$\mathrm{X}$ & $*$ & $* * *$ & $* * *$ \\
$\mathrm{Y}$ & $*$ & $* * *$ & $* * *$ \\
$\mathrm{Z}$ & $*$ & $* * *$ & $* * *$ \\
Coverage area & & & $* *$
\end{tabular}

$\bar{L}$ lightness, $a$ green-red colour component, $b$ blue-yellow colour component, $c$ chroma, $h$ hue angle, $H L$ delta L, $H a$ delta a, $H b$ delta b compared to white standard, $X$ chromaticity in $\mathrm{X}$ axis, $Y$ chromaticity in $\mathrm{Y}$ axis, $Z$ chromaticity in $\mathrm{X}$ axis

Table 8 Conventional descriptors with significant differences among means for sweet potato groups obtained in individual and combined analyses

\begin{tabular}{|c|c|c|c|}
\hline & Field characterization & Morpho-colourimetric characterization & Both analyses \\
\hline Length of the main vines & & $*$ & \\
\hline Vine internode length & & $*$ & \\
\hline Predominant vine colour & $* * *$ & $* * *$ & $* * *$ \\
\hline Secondary vine colour & & $* * *$ & \\
\hline Vine tip pubescence & & $*$ & \\
\hline Abaxial leaf vein pigmentation & & $*$ & $* *$ \\
\hline Mature leaf colour & $*$ & $* *$ & \\
\hline Mature leaf shape & $*$ & & \\
\hline Leaf lobes number & & & $*$ \\
\hline Flowering habit & $* * *$ & & $* * *$ \\
\hline Flower length $(\mathrm{cm})$ & $* * *$ & & $* * *$ \\
\hline Flower width $(\mathrm{cm})$ & $* * *$ & & $* * *$ \\
\hline Flower colour & $* * *$ & & $* * *$ \\
\hline Limb shape & $* * *$ & & $* * *$ \\
\hline Equality of sepal length & $* * *$ & & $* * *$ \\
\hline Number of sepal veins & $* * *$ & & $* * *$ \\
\hline Sepal shape & $* * *$ & & $* * *$ \\
\hline Sepal apex & $* * *$ & & $* * *$ \\
\hline Stigma colour & $* * *$ & & $* * *$ \\
\hline Style colour & $* * *$ & & $* * *$ \\
\hline Stigma exertion & $* * *$ & & $* * *$ \\
\hline Seed capsule set & $* *$ & & \\
\hline Storage root surface defects & $* * *$ & & $* * *$ \\
\hline Storage root cortex thickness & $* * *$ & & $* * *$ \\
\hline Predominant skin colour & $* * *$ & & $* * *$ \\
\hline Intensity of predominant skin colour & $* * *$ & & $* * *$ \\
\hline Secondary skin colour & $* * *$ & & $* * *$ \\
\hline Predominant flesh colour & $* * *$ & & $* * *$ \\
\hline
\end{tabular}


Table 8 continued

\begin{tabular}{llll}
\hline & Field characterization & Morpho-colourimetric characterization & Both analyses \\
\hline Secondary flesh colour & $* * *$ & $*$ & $* * *$ \\
Distribution of secondary flesh colour & $* * *$ & & $* * *$ \\
Storage root formation & $* * *$ & $* * *$ & $* *$ \\
Storage root stalk & $* *$ & $* * *$ \\
Number of storage roots per plant & $* * *$ & $* * *$ \\
Variability of storage root shape & $* * *$ & $* * *$ & $* * *$ \\
Variability of storage root size & $* * *$ & & \\
Latex production in storage roots & $* * *$ & $* * *$ & \\
Oxidation in storage roots & & & \\
Days to tuberous root formation & & & \\
\hline
\end{tabular}

$*, * *, * * *$ Significant differences at $p<0.05,0.001,0.0001$, respectively

Table 9 Number of significant $(p<0.05)$ differences among sweet potato group means for combined conventional descriptors and morphocolourimetric characters

\begin{tabular}{|c|c|c|c|c|c|c|c|c|c|c|c|c|}
\hline & \multicolumn{12}{|c|}{ Field and morphometric characterization } \\
\hline & A1 & B2 & A3 & A4 & A5 & B6 & B7 & B8 & B9 & $\mathrm{B} 10$ & B11 & $\mathrm{B} 12$ \\
\hline A1 & & 5 & 9 & 21 & 18 & 27 & 12 & 13 & 20 & 32 & 10 & 14 \\
\hline B2 & & 0 & 15 & 27 & 22 & 20 & 11 & 11 & 14 & 26 & 1 & 8 \\
\hline A3 & & & 0 & 12 & 24 & 32 & 3 & 7 & 20 & 21 & 14 & 12 \\
\hline A4 & & & & 0 & 11 & 26 & 16 & 14 & 33 & 11 & 26 & 25 \\
\hline A5 & & & & & 0 & 14 & 25 & 26 & 31 & 22 & 21 & 18 \\
\hline B6 & & & & & & 0 & 25 & 28 & 32 & 16 & 20 & 20 \\
\hline B7 & & & & & & & 0 & 1 & 18 & 17 & 8 & 9 \\
\hline B8 & & & & & & & & 0 & 22 & 17 & 16 & 18 \\
\hline B9 & & & & & & & & & 0 & 29 & 7 & 10 \\
\hline B10 & & & & & & & & & & 0 & 24 & 23 \\
\hline B11 & & & & & & & & & & & 0 & \\
\hline B12 & & & & & & & & & & & & 0 \\
\hline
\end{tabular}

Acknowledgements We thank Oswaldo Martinez and Manuel Hernandez for their technical support.

Authors' contributions AR and IP designed the experiment; LG, JP, DR, RM, AR and JM performed the experiment and wrote the manuscript; WB, AR and AM analysed the data; $\mathrm{EB}$ and AR wrote the manuscript. All authors have read and approved the manuscript for publication.

Funding This study was funded by Ministerio de Agricultura y Desarrollo Rural (MADR) of Colombia, through the Agreement No. 1828. The funding agency had no role in the study design, data collection and analysis, interpretation of results, and in the decision to publish or prepare the manuscript.

\section{Compliance with ethical standards}

Conflict of interest The authors declare that they have no conflict of interest.

Availability of data and materials The data sets supporting the conclusions of this article are included in this article and in its additional files.

Open Access This article is distributed under the terms of the Creative Commons Attribution 4.0 International License (http:// creativecommons.org/licenses/by/4.0/), which permits unrestricted use, distribution, and reproduction in any medium, provided you give appropriate credit to the original 
author(s) and the source, provide a link to the Creative Commons license, and indicate if changes were made.

\section{References}

Abramoff MD, Magalhaes PJ, Ram SJ (2004) Image processing with ImageJ. Biophotonics Int 11(7):36-42

Acheampong V (2012) Phenotypic and molecular characterization of released and elite sweet potato varieties in Ghana compared with virus-tested putative ramets. Master of Science thesis

Albert NW, Davies KM (2014) Schwinn KE (2014) Gene regulation networks generate diverse pigmentation patterns in plants. Plant Signal Behav 9(9):e29526. https://doi.org/10. 4161/psb.29526

Austin DF (1988) The taxonomy, evolution and genetic diversity of sweetpotatoes and related wild species. In: Gregory $\mathrm{P}$ (ed) Exploration, maintenance, and utilization of sweetpotato genetic resources. International Potato Center, Lima, pp 27-60

Austin DF, Huamán Z (1996) A synopsis of Ipomoea (Convolvulaceae). Am Taxon 45:3-38

Biot E, Cortizo M, Burguet J, Kiss A, Oughou M, MaugarnyCalès A, Gonçalves B, Adroher B, Andrey P, Boudaoud A, Laufs P (2016) Multiscale quantification of morphodynamics: MorphoLeaf software for $2 \mathrm{D}$ shape analysis. Development 143(18):3417-3428. https://doi.org/10. 1242/dev.134619

Blazakis KN, Kosma M, Kostelenos G, Baldoni L, Bufacchi M, Kalaitzis P (2017) Description of olive morphological parameters by using open access software. Plant Methods 13:111. https://doi.org/10.1186/s13007-017-0261-8

Brewer MT, Lang L, Fujimura K, Dujmovic N, Gray S, van der Knaap E (2006) Development of a controlled vocabulary and software application to analyze fruit shape variation in tomato and other plant species. Plant Physiol 141(1):15-25

Chavent M, Kuentz V, Simonet B, Liquet Saracco J (2012) ClustOfVar: an $\mathrm{R}$ package for the clustering of variables. J Stat Softw 50(13):1-16

Chitwood DH, Kumar R, Headland LR, Ranjan A, Covington MF, Ichihashi Y, Fulop D, Jiménez-Gómez JM, Peng J, Maloof JN, Sinha NR (2013) A quantitative genetic basis for leaf morphology in a set of precisely defined tomato introgression lines. Plant Cell 25(7):2465-2481. https:// doi.org/10.1105/tpc.113.112391

Chitwood DH, Ranjan A, Martinez CC, Headland LR, Thiem T, Kumar R, Covington MF, Hatcher T, Naylor DT, Zimmerman S, Downs N, Raymundo N, Buckler ES, Maloof JN, Aradhya M, Prins B, Li L, Myles S, Sinha NR (2014) A modern ampelography: a genetic basis for leaf shape and venation patterning in grape. Plant Physiol 164(1):259-272. https://doi.org/10.1104/pp.113.229708

Clarke AC (2009) Origins and dispersal of the sweet potato and bottle gourd in Oceania: implications for prehistoric human mobility: a thesis presented in partial fulfilment of the requirements for the degree of Doctor of Philosophy in Plant Biology at Massey University, Palmerston North, New Zealand
Cross RJ, Fautrier AG, McNeil DL (1992) IBPGR morphological descriptors-their relevance in determining patterns within a diverse spring barley germplasm collection. Theor Appl Genet 85(4):489-495. https://doi.org/10.1007/ BF00222331

Easlon HM, Bloom AJ (2014) Easy leaf area: automated digital image analysis for rapid and accurate measurement of leaf area. Appl Plant Sci. https://doi.org/10.3732/apps.1400033

Figàs MR, Prohens J, Raigón MD, Fernández-de-Córdova $\mathrm{P}$, Fita A, Soler S (2015) Characterization of a collection of local varieties of tomato (Solanum lycopersicum L.) using conventional descriptors and the high-throughput phenomics tool tomato analyzer. Genet Resour Crop Evol 62(2):189-204

Food and Agriculture Organization of the United Nations (2016) FAOSTAT statistics database. FAO, Rome

Gehan MA, Fahlgren N, Abbasi A, Berry JC, Callen ST, Chavez L, Hoyer JS (2017) PlantCV v2: Image analysis software for high-throughput plant phenotyping. PeerJ 5:e4088

Glato K, Aidam A, Kane NA, Bassirou D, Couderc M, Zekraoui L, Vigouroux Y (2017) Structure of sweet potato (Ipomoea batatas) diversity in West Africa covaries with a climatic gradient. PLoS ONE 12(5):e0177697

Huamán Z (1991) Descriptors for sweet potato. International Board or Genetic Resources, Rome. Centro Internacional de la Papa. Asian Vegetable Research and Development Center

Huamán Z (1999) Sweetpotato germplasm management (Ipomoea batatas) training manual. International Potato Center (CIP), Lima

Itle RA, Kabelka EA (2009) Correlation between L*a*b* color space values and carotenoid content in Pumpkins and Squash (Cucurbita spp.). HortScience 44(3):633-637. https://doi.org/10.21273/hortsci.44.3.633

Kadir A, Nugroho LE, Susanto A, Santosa PI (2011) Leaf classification using shape, color, and texture features. Int J Comput Trends Technol 3:230-255

Kaushik P, Prohens J, Vilanova S, Gramazio P, Plazas M (2016) Phenotyping of eggplant wild relatives and interspecific hybrids with conventional and phenomics descriptors provides insight for their potential utilization in breeding. Front Plant Sci 7:677. https://doi.org/10.3389/fpls.2016. 00677

Kendal D, Hauser CE, Garrard GE, Jellinek S, Giljohann KM, Moore JL (2013) Quantifying plant colour and colour difference as perceived by humans using digital images. PLoS ONE 8(8):e72296. https://doi.org/10.1371/journal. pone.0072296

Koussao S, Gracen V, Asante I, Danquah EY, Ouedraogo JT, Baptiste TJ, Jerome B, Vianney TM (2014) Diversity analysis of sweet potato (Ipomoea batatas [L.] Lam) germplasm from Burkina Faso using morphological and simple sequence repeats markers. Afr J Biotechnol 13(6):729-742. https://doi.org/10.5897/ajb2013.13234

Kumar J, Pratap A, Kumar S (2015) Plant phenomics: an overview. In: Kumar J, Pratap A, Kumar S (eds) Phenomics in crop plants: trends, options and limitations. Springer, New Delhi, pp 1-10

Lebot V (2010) Sweet potato, chapter 3. In: Bradshaw JE (ed) Root and tuber crops. Handbook of plant breeding, vol 7. Springer, Berlin, pp 97-125 
Liao F, Peng J, Chen R (2017) LeafletAnalyzer, an automated software for quantifying, comparing and classifying blade and serration features of compound leaves during development, and among induced mutants and natural variants in the legume Medicago truncatula. Front Plant Sci 8:915. https://doi.org/10.3389/fpls.2017.00915

Lockhart J (2013) A quantitative genetic basis for leaf morphology is revealed in a set of precisely defined tomato introgression lines. Plant Cell 25(7):2379. https://doi.org/ 10.1105/tpc.113.250710

Lopez AF, Gomez PA (2004) Comparison of color indexes for tomato ripening. Horticult Bras 22(3):534-537

Maechler M, Rousseeuw P, Struyf A, Hubert M, Hornik K (2018) Cluster: cluster analysis basics and extensions. R package version 2.0.7-1

Maquia I, Muocha I, Naico A, Martins N, Gouveia M, Andrade I, Ribeiro AI (2013) Molecular, morphological and agronomic characterization of the sweet potato (Ipomoea batatas L.) germplasm collection from Mozambique: genotype selection for drought prone regions. South Afr J Bot 88:142-151

Marmolejo DF, Santa R, Brito de Araújo G, Santana F, da Silveira S, Ferreguetti GA, Cancela HL, Viana AP, Gonzaga M (2017) Model-assisted phenotyping by digital images in papaya breeding program. Sci Agric 74(4):294-302

Mlodzinska E (2009) Survey of plant pigments: molecular and environmental determinants of plant colors. Acta Biol Crac Ser Bot 51(1):7-16

Montenegro Á, Avis C, Weaver A (2008) Modeling the prehistoric arrival of the sweet potato in Polynesia. J Archaeol Sci 35:355-367

Mwanga RO, Andrade MI, Carey EE, Low JW, Yencho GC, Grüneberg WJ (2017) Sweetpotato (Ipomoea batatas L.). In: Genetic improvement of tropical crops. Springer, Cham, pp 181-218

Nicotra A, Leigh A, Boyce CK, Jones CS, Niklas KJ, Royer DL, Tsukaya $H$ (2011) The evolution and functional significance of leaf shape in the angiosperms. Funct Plant Biol 38:535-552

Plazas M, Andújar I, Vilanova S, Gramazio P, Herraiz FJ, Prohens J (2014) Conventional and phenomics characterization provides insight into the diversity and relationships of hypervariable scarlet (Solanum aethiopicum L.) and gboma (S. macrocarpon L.) eggplant complexes. Front Plant Sci 5:318. https://doi.org/10.3389/fpls.2014.00318

Rahaman EHMS, Mahmud AA, Hossain M, Mohanta HC, Rahman MA, Khan MSI, Bonierbale M (2015) Field performance of sweet potato varieties in saline zone of Bangladesh. Bangladesh Hortic 1(1-2):67-76

Rodríguez AM, Tejón AM, del Sol DR, Vargas IJP, Méndez CA (2017) Origen, evolución y distribución del boniato (Ipomoea batatas (L.) Lam.). Una revisión. Agric Trop 3(1):1-13

Roullier C, Kambouo R, Paofa J, McKey D, Lebot V (2013) On the origin of sweetpotato (Ipomoea batatas (L.) Lam.) genetic diversity in New Guinea, a secondary centre of diversity. Heredity 110(6):594-604. https://doi.org/10. 1038/hdy.2013.14

Rousseeuw PJ (1987) Silhouettes: a graphical aid to the interpretation and validation of cluster analysis. J Comput Appl Math 20:53-65

Scaglion R (2005) Kumara in the Ecuadorian Gulf of Guayaquil? In: Ballard C, Paula B, Bourke RM, Harwood T (eds) The Sweet Potato in Oceania: a reappraisal. Oceania Publications, Sydney, pp 36-41

Schmittmann O, Schulze Lammers PA (2017) True-color sensor and suitable evaluation algorithm for plant recognition. Sensors (Basel). https://doi.org/10.3390/s17081823

Tanaka Y, Sasaki N, Ohmiya A (2008) Biosynthesis of plant pigments: anthocyanins, betalains and carotenoids. Plant J 54(4):733-749. https://doi.org/10.1111/j.1365-313X. 2008.03447.x

Templar S, Berenyi M, Zhang D, Hermann M, Schmidt J, Glo J, Burg K (2003) Genetic diversity in sweet potato [Ipomoea batatas (L.) Lam.] in relationship to geographic sources as assessed with RAPD markers. Genet Resour Crop Evol 50:429-437

Veasey EA, Silva JRDQ, Rosa MS, Borges A, Bressan EDA, Peroni N (2007) Phenology and morphological diversity of sweet potato (Ipomoea batatas) landraces of the Vale do Ribeira. Sci Agric 64(4):416-427

Vergara-Díaz O, Zaman-Allah MA, Masuka B, Hornero A, Zarco-Tejada P, Prasanna BM, Cairns JE, Araus JL (2016) A novel remote sensing approach for prediction of maize yield under different conditions of nitrogen fertilization. Front Plant Sci 18(7):666. https://doi.org/10.3389/fpls. 2016.00666

Yen DE (1982) Sweetpotato in historical perspective. In Villareal RL, Griggs TD (eds) Sweet potato: proceedings of first international symposium. AVRDC publ. no. 82-172, Tainan, Taiwan, China, pp 17-30

Zhang DP, Cervantes J, Huamán Z, Carey E, Ghislain M (2000) Assessing genetic diversity of sweet potato (Ipomoea batatas (L.) Lam.) cultivars from tropical America using AFLP. Genet Resour Crop Evol 47:659-665

Zhang D, Rossel G, Kriegner A, Hijmans R (2004) AFLP assessment of diversity in sweetpotato from Latin America and the Pacific region: Its implications on the dispersal of the crop. Genet Resour Crop Evol 51(2):115-120

Zhang C, Halsey LE, Szymanski DB (2011) The development and geometry of shape change in Arabidopsis thaliana cotyledon pavement cells. BMC Plant Biol 11:27. https:// doi.org/10.1186/1471-2229-11-27

Publisher's Note Springer Nature remains neutral with regard to jurisdictional claims in published maps and institutional affiliations. 